Illinois State University

ISU ReD: Research and eData

Theses and Dissertations

10-13-2014

\title{
Advocating For Advocacy: How Academia Affects Students' Civic And Political Engagement Outcomes
}

Chandler S. Johnson

Illinois State University, kalimizzou@gmail.com

Follow this and additional works at: https://ir.library.illinoisstate.edu/etd

Part of the Communication Commons, and the Education Commons

\section{Recommended Citation}

Johnson, Chandler S., "Advocating For Advocacy: How Academia Affects Students' Civic And Political Engagement Outcomes" (2014). Theses and Dissertations. 273.

https://ir.library.illinoisstate.edu/etd/273

This Thesis is brought to you for free and open access by ISU ReD: Research and eData. It has been accepted for inclusion in Theses and Dissertations by an authorized administrator of ISU ReD: Research and eData. For more information, please contact ISUReD@ilstu.edu. 


\title{
ADVOCATING FOR ADVOCACY: HOW ACADEMIA AFFECTS STUDENTS' CIVIC AND POLITICAL ENGAGEMENT OUTCOMES
}

\author{
Chandler S. Johnson
}

98 Pages

December 2014

This thesis explores the relationship between classroom interaction and students' behavioral outcomes. To investigate this relationship, the research applies the theory of planned behavior to identify civic engagement outcomes produced by teaching and classroom exposure. The results indicate that there is no significant relationship between the forms of teaching (i.e., active or passive) and behavior outcomes (e.g., self-efficacy). Nevertheless, results supported previous literature by showing that attitudes, selfefficacy, and subjective norms can predict behavioral intent. The results also showed a possible fatigue effect due to overexposure to civic and political engagement in the classroom. 


\section{ADVOCATING FOR ADVOCACY: HOW ACADEMIA AFFECTS STUDENTS' CIVIC AND POLITICAL ENGAGEMENT OUTCOMES}

CHANDLER S. JOHNSON

A Thesis Submitted in Partial Fulfillments of the Requirements for the Degree of

MASTER OF SCIENCE

School of Communication

ILLINOIS STATE UNIVERSITY 
(C) 2014 Chandler S. Johnson 


\section{ADVOCATING FOR ADVOCACY: HOW ACADEMIA AFFECTS STUDENTS' CIVIC AND POLITICAL ENGAGEMENT OUTCOMES}

CHANDLER S. JOHNSON

COMMITTEE MEMBERS:

John R. Baldwin, Chair

Kevin R. Meyer

Stephen K. Hunt 


\section{ACKNOWLEDGMENTS}

There are many individuals who are responsible for helping me get to this point in my life as a student, a scholar, and overall person. I would like this moment thank some of these special individuals now:

First and foremost, I would like to thank Dr. John R. Baldwin, the chairperson of this thesis. Words cannot express how grateful I am to have Dr. Baldwin advise me on this scholarly journey. His patience, guidance, humor, and selflessness are the quintessential reasons why Dr. Baldwin is an excellent instructor, mentor, and person. Dr. Baldwin, you are a brilliant person and I would not have successfully completed this thesis if it were not for you. Thank you so much for being my guide throughout this experience. I will never forget your teachings.

I would also like to thank my other two thesis committee members: Dr. Kevin R. Meyer and Dr. Stephen K. Hunt. Dr. Meyer taught me to be persistent in my search for knowledge. I recall the many Skype conversations we had in order to make sure my research was thoughtful and accurate. It is in these moments that I learned to execute with precision. To Dr. Meyer, thank you for challenging me to be persistent in my studies and research. You are an outstanding professor and you have an amazing talent for quantitative studies. Dr. Hunt taught me to be passionate about my research. He is always looking forward and constantly trying to fire people up about learning. Throughout the thesis and my academic career at Illinois State University, Dr. Hunt has always been willing to take my ideas and make them a reality. To Dr. Hunt, thank you for showing me 
what it truly means to be civically engaged. You are a man of the people and an outstanding professor to have on a committee. Thank you so much for everything.

Nevertheless, this journey in academia did not begin with these three amazing mentors. Throughout my life, I have been fortunate to encounter instructors and teachers who go beyond the call of duty to help foster a student's future. I would like to thank the men and women who have taught me that education is one of the cornerstones of success. More specifically, I would to thank Judith Loganbill, Rosemary Cauley, Joni Sylvester, Stan Smith, Kelly Furnas, Ryan Button, Andrea Button, Soo-Hye Han, Steve Harvey, Megan Koch, Megan Hopper, Craig Brown, and Bobby Imbody for their commitment to teaching. You all have taught me valuable lessons about being a good member of society and for that, I thank you.

Next, I would like to thank my family for being a foundation for me to grow. To my parents, Brad and Greta Burns, thank you for never giving up on me. In your own ways, you two have giving me traits and skills that will continually help me achieve my goals. I hope that I continue to make you proud and that my accomplishments reflect your great teaching. To my grandparents, Jerry, Peggy, Walter, and Willetta, thank you for teaching to be prepared, to be joyful, to be hard-working, and to be independent. To my uncles, Craig and Walter Jr., thank you for taking interest in my hobbies and passions. You two have been an amazing soundboards and I appreciate that you take the time to hear me out. To Morgan, Ashley, and Tyler, thank you for being the best three siblings an older brother could ask for. Each of you push me to be the best older brother I can be, but the truth is that I would be nothing without the three of you in my life. We're family and that is all that needs to be said on that subject. 
Additionally, I want to thank all my friends who have put up with me throughout the years. I know at times I come across as a grumpy person, especially when researching, but you were there when I needed you the most. To my gang of friends from Kansas State University, thank you for being my alternative family. To my friends in graduate school, thank you for helping me realize the person I want to be.

Lastly, I want to send a very special thank you to my friend who reminded me that excellence is habit and that I should always strive to be the best me. Thank you. I will continually strive to be better. This thesis is a testament to perseverance, learning, and having an amazing support system, from teachers to family. Thank you to everyone who has been involved in my journey. I greatly appreciate it.

Ad astra per aspera

C. S. J. 


\section{CONTENTS}

Page

ACKNOWLEDGMENTS

CONTENTS

TABLES vii

FIGURES viii

CHAPTER

I. RATIONALE AND REVIEW OF LITERATURE 1

$\begin{array}{ll}\text { Review of Literature } & 4\end{array}$

The Comprehensive Perspective of Civic and Political

Engagement 4

Defining civic engagement $\quad 5$

Defining political engagement or participation $\quad 7$

Defining service-learning $\quad 8$

Summary of definitions 9

Civic and Political Engagement in Higher Education 11

The implementation of civic and political engagement in higher education 11

Political engagement project 13

The impact of civic and political engagement in higher education

Instructional Communication and Pedagogy 16

Student involvement theory $\quad 18$

Active learning and passive learning $\quad 19$ 
The Relationship between Human Thought and Action

Theory of reasoned action

Theory of planned behavior

Research Questions

Conclusion

II. METHODS

Participants

Data Collection

Data Analysis

Conclusion

III. RESULTS

Results Summary

Teaching Predicting Future Engagement

Attitudes, Norms, and Self-Efficacy Predicting Engagement

Curvilinear Relationship between Engagement and Exposure and Behavioral Intent

Linear

Quadratic

Cubic

Growth 
$\begin{array}{ll}\text { IV. DISCUSSION } & 57\end{array}$

$\begin{array}{ll}\text { Summary of Findings } & 57\end{array}$

Teaching Styles and Future Engagement $\quad 57$

Attitudes, Norms, Self-Efficacy, and Future Engagement 61

Classroom Exposure and Self-Efficacy 61

Classroom Exposure and Behavioral Intent 62

Strengths and Limitations $\quad 64$

Limitations and Directions for Future Research 64

Limitations 64

Recommendations for future research 65

$\begin{array}{ll}\text { Practical Implications } & 68\end{array}$

$\begin{array}{ll}\text { Conclusion } & 70\end{array}$

$\begin{array}{ll}\text { REFERENCES } & 71\end{array}$

$\begin{array}{lll}\text { APPENDIX A } & \text { Survey Instrument } & 82\end{array}$

$\begin{array}{lll}\text { APPENDIX B } & \text { Informed Consent } & 91\end{array}$

$\begin{array}{lll}\text { APPENDIX C } & \text { Copyright Permission Letter }\end{array}$ 


\section{TABLES}

Table

Page

1. Beta Weights for One-Way and Two-Way Teaching on

Attitudes toward Civic Engagement

2. Beta Weights for One-Way and Two-Way Teaching on Self-Efficacy towards Civic Engagement

3. Beta Weights for One-Way and Two-Way Teaching on Behavioral Intention towards Future Civic Engagement

4. Results of Independent T-Tests of Self-Efficacy, Attitudes and Behavioral Intention by Year in School

5. Beta Weights for Attitudes, Norms, and Self-Efficacy on Future Civic Engagement

6. Beta Weights for Self-Efficacy for Civic Engagement on Classroom Exposure

7. Beta Weights for Intent toward Future Civic Engagement on Classroom Exposure

8. Linear - Beta Weights for Behavioral Intention on Engagement Exposure

9. Quadratic - Beta Weights for Behavioral Intention on Engagement Exposure

10. Cubic - Beta Weights for Behavioral Intention on Engagement Exposure

11. Growth - Beta Weights for Behavioral Intention on Engagement Exposure

12. Exponential - Beta Weights for Behavioral Intention on Engagement Exposure 


\section{FIGURES}

Table $\quad$ Page

1. Model of the TPB 24

2. The Curvilinear Relationship between Classroom Exposure and Future Behavioral Intentions 


\section{CHAPTER I}

\section{RATIONALE AND REVIEW OF LITERATURE}

Civic engagement is one of the cornerstones of American citizenship and social responsibility. As a component of the American Dream, civic engagement can weave together a tapestry of individuals and ethnicities to work toward common goals.

Furthermore, American ideologies suggest that citizens should recognize that they are part of a larger social condition and they should seek to make impacts civically and democratically (Hoekema \& Ehrlich, 2000). Balsano (2005) asserts that, in order for civic-mindedness to develop among individuals, people need to be presented with civically engaging experiences throughout their lives. One of the main ways a mindset for civic engagement is being fostered is through the classroom experience.

Many studies (e.g., Balsano, 2005; Hillygus, 2005; Torney-Purta, 2002) have shown that there is a relationship between education and civic engagement. Furthermore, Dewey (1981) suggests that teaching civic engagement terms and principles in primary, secondary, and higher education can significantly impact an individual's perspective on civic engagement outside of the classroom (Dewey, 1981). The integration of civic engagement in the classroom can also bridge relational gaps between adults (e.g., teachers) and youths (e.g., students), allowing them to converse about communal issues and develop shared meanings about the world (Minkoff, 1997; Putnam, 1993). 
The experiences, interactions, and information presented in school-sponsored civic engagement activities can have a lasting impact on student behavior (Beaumont, Colby, Ehrlich, \& Torney-Purta, 2006; Spiezio, Baker, \& Boland, 2006). Exposure to domestic or foreign perspectives, engaging in communal values, and gaining interdisciplinary skills or traits are some of transferrable concepts to being a civically engaged citizen. Eccles and Barber (1999) argue that civic engagement activities in the classroom can correlate to positive educational outcomes (e.g., grades), as well as these events empowering students to make positive life choice.

However, many studies express negative results regarding individuals, specifically young adults, participating in civic engagement activities in the United States (Galston, 2001; Macedo, 2005; Putnam, 2000). Currently, young adults are not only participating in civic activities less than their older counterparts, but they are contributing much less than they did a decade ago (Goss, 2000). While 8.2 million college students volunteered to join national and international programs, like Teach for America or the Peace Corps, in 2008 (Corporation for National and Community Service, 2009), studies suggest there is an attitudinal shift in college students from volunteerism to being more concerned about personal gains (Macedo, 2005; Myers-Lipton, 1998; Shapiro, 2000). Additionally, those that do participate in civic engagement activities contribute with less awareness of or passion towards the issues (Macedo, 2005). This form of participation is arguably comparable to no involvement in the activity because of the participants' uninformed approach to activism. Some scholars attribute this approach to the lack of meaningfulness developed from participating in civic engagement activities in the classroom (Evan \& Prilleltensky, 2007; Hart, 1992; Goss, 2000), perhaps because 
most such activities involve one-way teaching, with students as passive learners (Torney Purta, 2002).

Given that education has the potential to develop a significant impact on an individual's civic engagement behavior, more research is necessary to better understand how this interaction works. Past scholars have shown how aspects of communication discipline affect the role education plays in the civic engagement curriculum (Hillygus, 2005; Lamm, 2009; Locklin, 2012; Murphy, 2004); however, “most studies that link classroom practices to civic commitments are relatively small scale in nature, focus on very specialized curricula, and therefore are not easily generalized" (Kahne \& Sporte, 2008, p. 741). There needs to be more research exploring how a student's perception of civic engagement activities changes over time in college, especially how adulthood. Results from this the present exploration could have significant implications for the field of communication and the curriculum of civic engagement across all educational disciplines. Moreover, communities are in need of young people contributing ideas and their time to improve social issues now. For, as Keiser (2000) writes, "We do not have the liberty to wait ten years to reverse the trends of apathy and cynicism among today's young adults" (p. 36). Thus, the general purpose of this study is to explore whether classroom experience affects students' self-efficacy for civic engagement, as well as their likelihood to be civically engaged in the future. To address this purpose, the present study will provide a review of literature defining civic engagement, political engagement, and service-learning, as well as the role of civic engagement in education, specifically in higher education. Then, literature will be provided examining instructional communication and pedagogy, followed by a theoretical framework predicting civic 
engagement behavior. This section will discuss the formation of the theory of planned behavior (TPB) and evaluate the role of self-efficacy in the model. Finally, research questions will be presented to further explain the direction of this study.

\section{Review of Literature}

\section{The Comprehensive Perspective of Civic and Political Engagement}

In the past 20 years, civic engagement has grown to become one of the core teachings in academia to develop a student's mind toward social responsibility. While progress has been made on the conceptualization of civic engagement, it is still a complex subject that many researchers (e.g., Butin, 2006; Dewey, 1981; Ehrlich, 2000; Hunt, 2010; Jacoby, 2009; Zlotkowski, 1999) are continually trying to define and describe. There are many studies that analyze civic responsibility within the community; however, these studies use a plethora of terms to describe similar concepts, including political engagement, citizenship, community service, service-learning, democratic participation, public work, community building, citizen involvement, civic engagement, and social justice (Battistoni, 2002; Jacoby, 2009; Levine, 2007; Saltmarsh, 2005). The polynymy of "civic engagement" is initially due to multiple academic fields, in multiple locations, trying simultaneously to define this concept during its conception (Locklin, 2012). Thus, the variety of vocabulary has made it difficult for researchers and scholars to choose words that will be recognized by the majority of academic fields or organizations as the "true" term. In order to provide consistency throughout the present study, as well as minimalize confusion for the reader, the researcher has decided to use the term civic and political engagement to describe the form(s) of social responsibility occurring on campuses. Furthermore, civic and political engagement and engagement 
shall be umbrella terms for three commonly described concepts in this discipline: civic engagement, political engagement, and service-learning. This section of the review of literature will briefly describe and define the three concepts that make-up civic and political engagement. Then, this section will provide a brief summary consolidating these three concepts for the use of the present study.

Defining civic engagement. Defining civic engagement has been an ongoing endeavor in academia. This is primarily due to researchers not using the term "civic engagement" consistently when incorporating this concept in their studies. Researchers tend to bundle a variety of engagement strategies to form their own makeshift definition of civic engagement (Saltmarsh, 2005) Therefore, depending on the study, civic engagement encompasses many different social phenomena, including communal events, public forums, politics, and other forms of social action. The historical variance and multifacetedness of civic engagement cause it to be defined in many ways (Shapiro, 2000). Downs (2012) defines civic engagement as "any activity, individual or collective, devoted to influencing the collective life of the polity" (p. 344). Another definition of civic engagement is that it is "the network of ties and groups through which people connect to one another and get drawn into community and political affair" (Skocpol \& Fiorina, 1999, p. 1).

Additionally, defining civic engagement facilitates the need to have a clearer discussion on the definition of what counts as "good" civic engagement. Some scholars argue that it is impossible to define civic engagement without inserting a definition on morality, ethics, or justice (Levine, 2007). If the intent of civic engagement is to make the world or a community a "better place," then categorizing specific events and activities as 
"good deeds" could create a disillusion that only certain actions will count as being civically engaged in the community. In other words, a "good deed" could include a wide array of actions.

Thus, a working definition of civic engagement needs to be characterized by flexibility for a variety of "good deeds." Initially framed by the Coalition for Civic Engagement and Leadership, the definition by Jacoby (2009) provides a broader description of civic engagement as:

Acting upon a heightened sense of responsibility to one's communities. This includes a wide range of activities, including developing civic sensitivity, participation in building civil society, and benefiting the common good. Civic engagement encompasses the notions of global citizenship and interdependence. Through civic engagement, individuals - as citizens of their communities, their nations, and the world — are empowered as agents of positive social change for a more democratic world. (p. 9)

Jacoby's definition for civic engagement will be the working definition for this study. Civic engagement can arguably encapsulate public affairs, involvement in community associations such as clubs and religious bodies, associations with work organizations and unions, and informal happenings such as sports leagues, picnics, parties, and even politics (Shapiro, 2000). However, some scholars (Colby, Beamont, Ehrlich, \& Corngold, 2007) have presented alternative definitions that primarily focus on political and democracy engagement. 
Defining political engagement or participation. As with civic engagement, writers on political engagement have produced a substantial catalog of definitions and descriptions. In some cases, civic and political engagement do not have clear distinctions between each other and at times can be seen as blurring into one another (Colby et al., 2007). However, participating in politics can range from activities with little commitments (e.g., joining a student-run political organization or blogging about campaigns) to big commitments (e.g., running for class president or coordinating a political fundraiser) (Boyd \& Brackmann, 2012). Thus, political participation concentrates on stimulating respectful debates and discussions about public problems, democratic situations, and governmental issues (Bohman, 1997. Additionally, Colby et al. (2007) argue that political participation should not include topics like energy conservation, lifestyle choices, or food consumption preferences unless they relate to institutional, governmental, or societal change. This study presents a working definition for political engagement that "suggests the action of political participation but also the development of political skills, motivation, and political efficacy to understand students' role in the political process" (Boyd \& Brackmann, 2012, p. 49).

While the present study has attempted to clearly define civic engagement and political engagement, this researcher cannot deny that there is a strong relationship between these two activities. Some scholars suggest that civic engagement is often the cause of people becoming politically engaged (Colby et al., 2007; Putnam, 2000; Wilkin, Katz, \& Ball-Rokeach, 2009). Additionally, Battistoni (1997) argues that youth are more inclined to engage in civic activities because they present fewer requirements for 
participation, while adults have an easier opportunity to engage politically or provide resources to link the two aspects together.

Defining service-learning. The method of service-learning creates another dimension to the dialogue of civic engagement, political engagement, and the sense of communal interaction. Service-learning is not typically seen as an item that serves as an umbrella for civic and political engagement. Instead, service-learning operates as its own entity with the intention of impacting civic engagement and political engagement outcomes. Therefore, service-learning is seen to have more of a horizontal relationship than vertical relationship with civic and political engagement.

Service-learning is a rising method of teaching used in many classrooms, especially on college campuses and universities. The method attempts to heighten students' sense of community, while emphasizing critical thinking and personal reflection skills. The technique has a major presence in higher education, with hundreds of colleges and universities incorporating the method into their curriculum (Butin, 2006; Knapp, Fisher, \& Levesque-Bristol, 2010). Some scholars, like Battistoni (1997), believe that service-learning is a powerful practice that is designed to promote active participation to develop citizenship skills. Others (e.g., Butin, 2006) point out that service-learning is frequently seen by faculty members as a time-consuming, conjectural practice that hinders promotion and tenure. Nevertheless, service-learning is transforming the way people view the classroom experience (Eyler, Giles, Stenson, and Gray 2001).

Consistent with the difficulty of defining civic engagement and political engagement, service-learning implies different things to different people. For example, Furco (2002) believes, "Service-learning seeks to engage individuals in activities that 
combine both community service and academic learning. Because service-learning programs are typically rooted in formal courses (core academic, elective, or vocational), the service activities are usually based on particular curricular concepts that are being taught” (p. 25). Bringle and Hatcher (1996) argue that service-learning is:

A credit-bearing educational experience in which students participate in an organized service activity that meets identified community needs and reflect on the service activity in such ways as to gain further understanding of course content, a broader appreciation of the discipline, and an enhanced sense of civic responsibility. (p. 222)

For the present study, the researcher will use Bringle and Hatcher's description of service-learning as the working definition.

Summary of definitions. Civic engagement has become an overarching concept under which faculty, administrators, and students think about, argue about, and attempt to implement a variety of visions of higher education in service to society (Lawry, Laurison, \& VanAntwerpen, 2006). Scholars, researchers, and organizations are constantly trying to figure out the best way to operationalize the idea of civic engagement, especially when it comes to implementing these concepts (i.e., civic engagement, political engagement, and service-learning) in the classroom. However, the theoretical complexity of the concepts hinders their progression to a more succinct discipline.

The previous sections addressed the multiple descriptions of civic engagement, political engagement, and service learning, as well as provided a working definition for each term in this study. Arguably, in a broad sense, engagement aims: 
To make a difference in the civic life of our communities and developing the combination of knowledge, skills, values, and motivation to make that difference. It means promoting the quality of life in a community, through both political and non-political processes. (Hoekema \& Ehrlich, 2000, p. vi)

The present researcher understands that civic engagement, political engagement, and service-learning can each be divided into its own category. However, the aim of this study is to look at engagement as a single entity; therefore, the researcher intends to study all of the aspects within these three definitions as one unified concept. In order to avoid confusion, the researcher will use the terms, civic and political engagement or engagement to describe the use of civic engagement, political engagement, and servicelearning in the study.

This study is a comprehensive analysis of civic engagement, political engagement, and service-learning. It will examine how civic and political engagement is taught in the classroom, as well as describe its effects on students. Engagement requires a constant bond between knowledge and activism. A person being civically and politically engaged uses the tools and information she or he has acquired to enthusiastically assist in developing society. Higher education is a key component in the development of civic and political engagement skills. Higher education aims not only to educate students about the fundamentals of civic and political engagement, but also aids in developing their internal motivation to identify and interact with the community on social issues. The classroom provides a setting for training and reflection setting that individuals can use to explore the arena of civic and political engagement, as well as shape the way we define it in the future. 


\section{Civic and Political Engagement in Higher Education}

Higher education is a powerful component in shaping the way individuals view civic and political engagement. Furthermore, scholars argue that civic and political engagement in the classroom is an unique device that can gather younger and older adults to collaborate about issues they share similarly (Boyer, 1996; Cantor, 2004; Checkoway, 2001; Harkavy, 2006; Minkoff, 1997; Putnam, 1993). Some scholars adhere to the belief that civic and political engagement education is the root to developing active and civically responsible citizens in society (Balsano, 2005). In 2008, Kahne and Sporte studied the sources of exposure that impact good practices in civic education, including family, friends, the community (e.g., neighborhood), and school. Analyzing 4,057 participants from 52 high schools in Chicago, most from low-income backgrounds, they found that classrooms have a significant impact on students' commitments to civic and political engagement. While other factors have their own distinctive impact on civic and political engagement, school can facilitate positive civic discussions and behavior throughout students' upbringing. This section of the review of literature briefly transitions the working definition(s) into methods utilized in college and university classrooms. This section will also provide past evidence of the implementation of these methods.

The implementation of civic and political engagement in higher education.

Scholars believe that the college and university experience is arguably the capstone to promoting civic engagement (Locklin, 2012). It is the quintessential time for young adults to investigate the world around them by collaborating with different national and international individuals, joining campus organizations, and enrolling in courses that 
educate them about social issue or civic engagement (Youniss, 2009). With this type of human development in consideration, colleges and universities have been revising their academic curriculum and campus-wide campaigns to present a higher education that promotes civic and political engagement (London, 2001). Thus, civic and political engagement now comes in many forms (e.g., blood drives, voting centers, community booths, and social organizations) without being defined as civic engagement, political engagement, or service-learning (Finley, 2011).

Furthermore, colleges and universities have continued to implement of civic and political engagement values into the classroom. Scholars (e.g., Butin, 2006; Hillygus, 2005) are exploring curriculums to see which courses are best suited for civic and political engagement. Butin (2006), for example, reveals that not all classes are suited for civic and political learning:

Hard-pure fields (e.g., chemistry and physics) view knowledge as cumulative and are concerned with universals, simplification, and quantification. Hard-applied fields (e.g., engineering) make use of hard, pure knowledge to develop products and techniques. Soft-pure fields (e.g., English) view knowledge as iterative and are concerned with particularity and qualitative inquiry. Soft-applied fields (e.g., education, management) make use of soft, pure knowledge to develop protocols and heuristics. What becomes immediately clear is that service-learning is overwhelmingly used in the "soft" disciplines. (p. 29)

The classes that can incorporate civic and political engagement have become sanctuaries for initiatives. Campaigns and organizations (e.g., Campus Compact, Association of American Colleges and Universities, American Democracy Project, and 
the Carnegie Foundation for the Advancement of Teaching) are studying and implementing such initiatives to better prepare students for citizenship. It is important to understand the background regarding how initiatives are attempting teach students about the importance of civic and political engagement. The Political Engagement Project is the perfect example to demonstrate the incorporation of civic and political engagement in college classrooms. Additionally, for this current study, the researcher used instruments from the Political Engagement Project to produce higher quality results.

Political engagement project. The Political Engagement Project (PEP) is an initiative that was created to help improve college education and foster it toward a more civically and politically engaged curriculum (Hunt, 2010). Studies reveal that incorporating civic participation in a course increases academic achievement (Astin, Vogelegesand, Ikeda, \& Yee, 2000; Colby et al., 2007; Eyler, Giles Stenson, \& Gray, 2001). Additionally, the program has created a variety of approaches to help develop engaged citizens. For example, political topics can help spur face-to-face discussions and deliberations. In turn, students develop skills that assist them to recognize their own beliefs and other people's points of views, and it teaches them about issues occurring in their community (Colby et al., 2007). By also incorporating readings, in-depth activities, and dynamic reflection assignments, schools that support PEP have seen better current and future engagement results among their students. In one study Hunt, Simonds, and Simonds (2009) find that students like a PEP version of the basic public speaking course better than traditional version. By making civic and political issues more significant and relatable, instructors have been able to increase student interest in community issues 
(Colby et al., 2007). Instructors can impact the future of society through their interactions with their students (Hunt, 2010).

The impact of civic and political engagement in higher education. In the 1970s, levels of civic and political engagement began steadily declined among college students (Flanagan \& Levine, 2010; Reinke, 2003), as well as most demographics (Putnam, 2000). While certain statistics have dramatically changed with the induction of civic and political engagement initiatives, some studies have presented possible reasons why people are disengaging from political and civic responsibility. Some studies have suggested that there are many reasons why young people do not participate in civically engaging activities. Initially, while college and university students have the opportunity to explore culture, higher education is also more of a transitional period in a person's life. Although students live in their college communities for a number of years, they identify the place they grew up as their "home" (Keiser, 2000); thus, they may choose not to get involved in what they perceive to be a temporary home.

Additionally, between exams and assignments, the college lifestyle could keep students busy and prevent them from experiencing the "greater city area" (Keiser, 2000). This creates a divide between the college community and the greater city community, in which the greater city populace becomes less inclined to interact with college students and promote activism in their community to those students.

While Rosenstone and Hansen (1993) contend that well-educated individuals will receive the schooling necessary to understand issues, like the abstract subjects of politics, such schooling does not help students operationalize their knowledge. Furthermore, the 
areas taught by colleges and universities span across many fields of study, which means that every student is getting a different university experience:

A social science curriculum has a consistent, positive and statistically significant effect on ... political engagement. The impact of a humanities curriculum is somewhat smaller and less consistent, but also trends to find a positive relationship with future participation.... The pattern for science and business school majors, on the other hand is just the opposite. In fact, an increase in the number of business and science course is correlated with a statistically significant decrease in political participation. (Hillygus, 2005, p. 37)

The Hart Research Association (2011) points out that college seniors only answered half of the questions correct on a test that measured civic knowledge. Further, it has been suggested that college graduates today know less about politics than high school graduates in 1950 (Galston, 2001). In addition, in 2007, the United States was ranked in the bottom percentile of voter turnout in the world (Hart, 2011). Some scholars argue that the civic participation perspective is evolving into more service and volunteerism, but not more involved forms of civic or political engagement (Hillygus, 2005). Conclusively, Keiser (2000) argues that although many students feel that they have an important voice, they feel no one is listening; this therefore affects their self-efficacy. Additionally, Mondak and Gearing (1998) argue that individuals who do not frequently interact with the community lack a vision of the importance of politics and civically engaging activities.

However, despite the possible reasons engagement was declining in the past, the incorporation of new engagement initiatives (e.g., American Democracy Project) and 
curriculum (e.g., PEP) into academia has made the future bright for citizenship. Spiezio et al. (2006) conducted a study at four colleges to analyze the impact of service-learning on students' attitudes toward civic engagement. The study, examining results from 1,243 participants, determined that teaching strategies could significantly impact the attitudes of students toward the importance of civic and political engagement. Furthermore, the integration of real-world experiences, like current political issues, through activities, discussions, and assignment can help reinforce notions that college students are an important part of the community (Colby et al., 2007).

\section{Instructional Communication and Pedagogy}

The link between engagement in the classroom and behavioral outcomes is communication, since communication is the key to transferring knowledge about civic engagement from one person to another. Communication is the fundamental teaching tool of civic engagement, whether it is through a written, spoken, or visual form. All university and college courses have some form of interaction to teach students about a particular subject, including civic engagement. Goodman and Refsing (2002) argue there are four functions of schooling: (1) educating, (2) socializing, (3) selecting, and (4) serving as a depository. The incorporation of civic engagement can successfully accomplish all four functions of Goodman and Refsing's functions.

However, a majority of civic knowledge is being taught through a one-way interaction with a textbook. In a 2002 study, Torney-Purta revealed that $90 \%$ of American students reported mainly learning about civic-related topic through conditioning-type activities, such as reading textbooks, answering worksheets, or doing memorization learning activities. The study goes on to explain that only half as many 
students are involved in debates, discussion, and other multi-dimensional conversations in the classroom.

Even when interactive assignments are present, the learning context is not devoid of power considerations. Goss (2000) argues that, while some institutions have discussions about civic engagement, the topic is usually presented in an authoritative way in which credible individuals are the only ones legitimized in the conversation. Some scholars have pointed out that some instructors, at times, more overtly enforce their ideas on the classroom. Kelly-Woessner and Woessner (2006) report that liberal college professors penalize students for expressing conservative opinions by assigning lower scores on exams and assignments. Furthermore, professors are more critical of work that contradicts their ideas. Out of 1,385 student at Elizabeth College and Penn, 32\% were "very confident" in identifying their instructors' ideology, followed by $40 \%$ who were "somewhat confident." Students were more inclined to answer assignments and test according to their instructors' beliefs instead arguing their own point. This form of teacher-student interaction creates a passive-receptive environment, in which the student feels inclined to communicate in a way that validates the authority of the instructor (Kochman, 1985).

The incorporation of civic and political engagement initiatives has helped change the frontier of instruction communication in a classroom setting. However, it is crucial that instructors consider that the way they promote critical thinking and engagement is just as important as incorporating the subject in their class. This section of the literature review presents concepts that support the idea that communication is the quintessential link between learning citizenship and behavioral outcomes. Furthermore, as the current 
study focuses on how teaching interaction affects outcomes, it is imperative that literature regarding communication or interaction be provided.

Student involvement theory. Initially, student involvement theory (SIT) describes how institutional environments (e.g., curriculum design, university policies, climate, and campus resources) and student behaviors (e.g., attentiveness, effort, timemanagement, and interactions with other students) merge to predict student outcomes in the present, as well as in the future after college (Astin, 1984; Kuh 2001, 2003). The term involvement is typically related to the literature of student engagement. Chapman (2003) states that student engagement 'depict[s] students' willingness to participate in routine school activities, such as attending class, submitting required work, and following teachers' directions in class" (p. 2).

SIT and student engagement literature argue that in order for students to have positive educational outcomes, instructors need to be constantly active in creating the best academic condition for students. Instructors achieve this goal by providing constructive feedback, developing a positive interpersonal relationship with students, incorporating multiple mediums of teaching, and many other techniques. Skinner and Belmont (1993) suggest that engaged students:

Show sustained behavioral involvement in learning activities accompanied by a positive emotional tone. They select tasks at the border of their competencies, initiate action when given the opportunity, and exert intense effort and concentration in the implementation of learning tasks; they show generally positive emotions during ongoing action, including enthusiasm, optimism, curiosity, and interest. (p. 572) 
Additionally, multiple studies have shown that student engagement significantly impacts student success (Anaya, 1996; Astin, 1984; Berger \& Milem, 1999; Bomia et al., 1997; Chickering \& Reisser, 1993; Hu \& Kuh, 2003). However, student engagement focuses on many other factors that do not specifically pertain to the current study. To keep the discussion succinct, the review of literature will on focus only on the impact of active (two-way teaching) and passive (one-way teaching) learning.

Active learning and passive learning. There are two types of learning that this study will be focusing on: active learning and passive learning. First, active learning is wide-range method that describes the type of teaching that primarily holds individuals responsible for learning the subject. Active learning (i.e., two-way teaching) centers on the notion of presenting opportunities for students to interact with the information and create their own interpretations from the interactions (Bonwell \& Eison, 1991). Thus, active learning can include role plays, field trips, debates, games, small group discussions, and experiments (Bonwell \& Eison, 1991; Ebert-May, Brewer, \& Allred, 1997; Sarason \& Banbury, 2004). Researchers suggest that students using active learning engage in higher-order thinking, which increases analyzing, evaluating, and creating within the student (Bonwell \& Eison, 1991).

Alternatively, passive learning (i.e., one-way teaching) is an approach that primarily focuses on the information being conveyed from one entity with little to no feedback from the learners. For example, traditional college lectures incite the instructor to be the only communicator, with the students taking the main role of receptors of the information (Wingfield \& Black, 2005). Passive learning can also involve reading assignments, multiple-choice tests, and short-answer assignments. This method of 
teaching allows the instructor to present a substantial amount of information with fewer time constraints (Miner, Das, \& Gale, 1984; Whetten \& Clark, 1996).

Some research has proclaimed that active learning is more effective than passive learning (Benek-Rivera \& Matthews, 2004; Dorestani, 2005). Splitter (1995) advocates that instructors should work to create critically thinking individuals instead of making students feel like they are going through a training course. Meaningful activities and interaction will have a more lasting impact with young adults than rudimentary assignments (Evans \& Prilletensky, 2007; Goss, 2000; Hart, 1992). Even though passive learning is used in a majority of classrooms, a large amount of data support that students are more attentive, retain information better, as well as provide their own interpretations to the material with active learning (Dorestani, 2005; Van Eynde \& Spencer, 1988;). However, more research is necessary to further determine the values of both methods.

\section{The Relationship between Human Thought and Action}

Communication and teaching have historically significant roots that link it to civic engagement (Battistoni, 2002; Coalition for Civic Engagement and Leadership, 2005; Colby et al., 2007; Locklin, 2012). Researchers have used a variety of methods to analyze the impact of communication on civic engagement behavior, including advertising campaigns (Brulle, 2010), social media (Weinstein, 2014), and familial interactions (Wilkin et al., 2009). Ajzen (1985) argues that exterior factors may impact a person's behavior intentions and that scholars should seek to decipher these impacts. For this study, Ajzen's $(1985,1987,1988,1989,1991,2005)$ TPB is an ideal theoretical framework to analyze possible future behaviors that might be developed from classroom situations and scenarios. The TPB evolved from the theory of reasoned action (TRA) 
(Fishbein \& Ajzen, 1977). The following provides an overview of the TRA and TPB, and a description of self-efficacy as it is added to the model of the TPB.

Theory of reasoned action. Fishbein and Ajzen (1977) developed the TRA to predict people's behavioral intentions, because according to the TRA, intentions are the true determinant to a person's behavior. External factors and social pressure can play a role in affecting an individual's intentions. However, the TRA suggests that individuals are in volitional control of their behaviors.

The TRA explains persuasion by means of four main components: behavior (B), behavioral intention (BI), attitude (A), and subjective norms (SN). Initially, a person may have numerous beliefs regarding a certain behavior; however only a few salient beliefs will be recognized at any given moment. These salient beliefs are determined by a person's attitudes and subjective norms. A person's attitudes weigh the beliefs regarding behavioral consequences against the particular evaluations of those consequences, while subjective norms identify the influence and expectation a person perceives to perform or not perform a particular behavior. Fishbein and Ajzen (1977) argue that an individual's attitudes (A) and subjective norms (SN) determine their behavior intention (BI), which overall affects whether or not they will perform the behavior (B). In its simplest form, the TRA can be presented symbolically as follows:

$$
\mathrm{B} \approx \mathrm{BI}=(\mathrm{A}) \mathrm{w}_{1}+(\mathrm{SN}) \mathrm{w}_{2}
$$

In the equation, $\mathrm{w}_{1}$ and $\mathrm{w}_{2}$ are empirically derived weights to identify the varying impacts attitude and subjective norm have on behavioral intention. In certain circumstances, attitude may have a greater impact in effecting the behavioral outcome than subjective norms and vice versa. 
Several studies (e.g., Sheppard, Hartwick, \& Warshaw, 1988; van den Putte, 1991) have shown the validity the TRA; however, the model has also received criticism for its measurement issues, lack of consistency, and the causal focus when predicting the attitude-behavior relationship. To begin, Sheppard et al. (1988) argue that the TRA aims to predict behaviors, unless the intent radically changes before performance or the individuals' intention does not link to the behavioral standard of the theory (e.g., action, target, context, or time frame). Moreover, scholars (Fazio, 1989; Fazio \& Zanna, 1981) criticize the TRA because the theory does not take into consideration a person's automatic ability to access attitudes from memory. Recent or more impactful experiences are more likely going to be more salient and quicker to access for the individual. However, the instantaneousness and unpredictability of previous attitudes from memory put into question the validity of the construct of attitude (Fazio, 1989). Scholars (Eagly \& Chaiken, 1995; Sarver, 1983; Songer-Nocks, 1976) also criticize the TRA for a lack of feedback within model, leaving no opportunity for individuals to change their beliefs or attitudes. Ultimately, Liska (1984) believes that the TRA's focus on only an individual's motivation toward a behavior is restricting and not inclusive to other factors that could impact a person's attitudes to perform or not perform a particular behavior. Considering the critiques toward the TRA, Ajzen $(1985,1988)$ developed the model into a more succinct framework.

Theory of planned behavior. Many scholars have used the TPB to better understand perceived behavioral control in a variety of scenarios such as healthcare (Godin \& Kok, 1996; Wang, 2009), the use of consumer products (Nocella, Boecker, Hubbard, \& Scarpa, 2012; Xiao, Tang, Serido, \& Shim, 2011), the use of mass media 
tools (Cha, 2013; Xiao Wang \& McClung, 2011), and in academic or classroom settings (MacFarlane \& Woolfson, 2013; Wheeless, Witt, Maresh, Bryand \& Schrodt, 2011). The TPB was developed to supply missing functions of the TRA in order to provide a better prediction of behavior. Ajzen (1988) states that "the theory of reasoned action was developed explicitly to deal with purely volitional behaviors" (p. 127). Further, he argues that external factors can impact a person's intention, which is important when predicting behavior. In 1988, Ajzen created the TPB also to analyze the factors of personal resources and environmental determinants on an individuals' behavior.

The TPB (see Figure 1) maintains notions from the TRA that a person's intention to perform a particular behavior directly impacts the actual performance of the behavior. Behavioral intention overall identifies the individual's attitude toward performing the behavior and the individual's perception of how others feel about performing the behavior. The TPB framework suggests that a person's intention to perform a specific behavior can be predicted through the person's attitudes, subjective norms, and perceived behavioral control (see Figure 1), thus predicting how he or she will react to the situation. More specifically, behavioral beliefs, normative beliefs, and control beliefs affect or influence a person's attitudes, subjective norms, and perceived behavioral control. The broken line between perceived control and behavior indicates that when a person's perception of control agrees with the person's actual control, perceived control will influence behavior directly as well as indirectly through intention (Ajzen, 1988). The more positive and encouraging the attitude, subjective norms, or perceived behavioral control, the more likely the person's intent will be to engage in the behavior. 


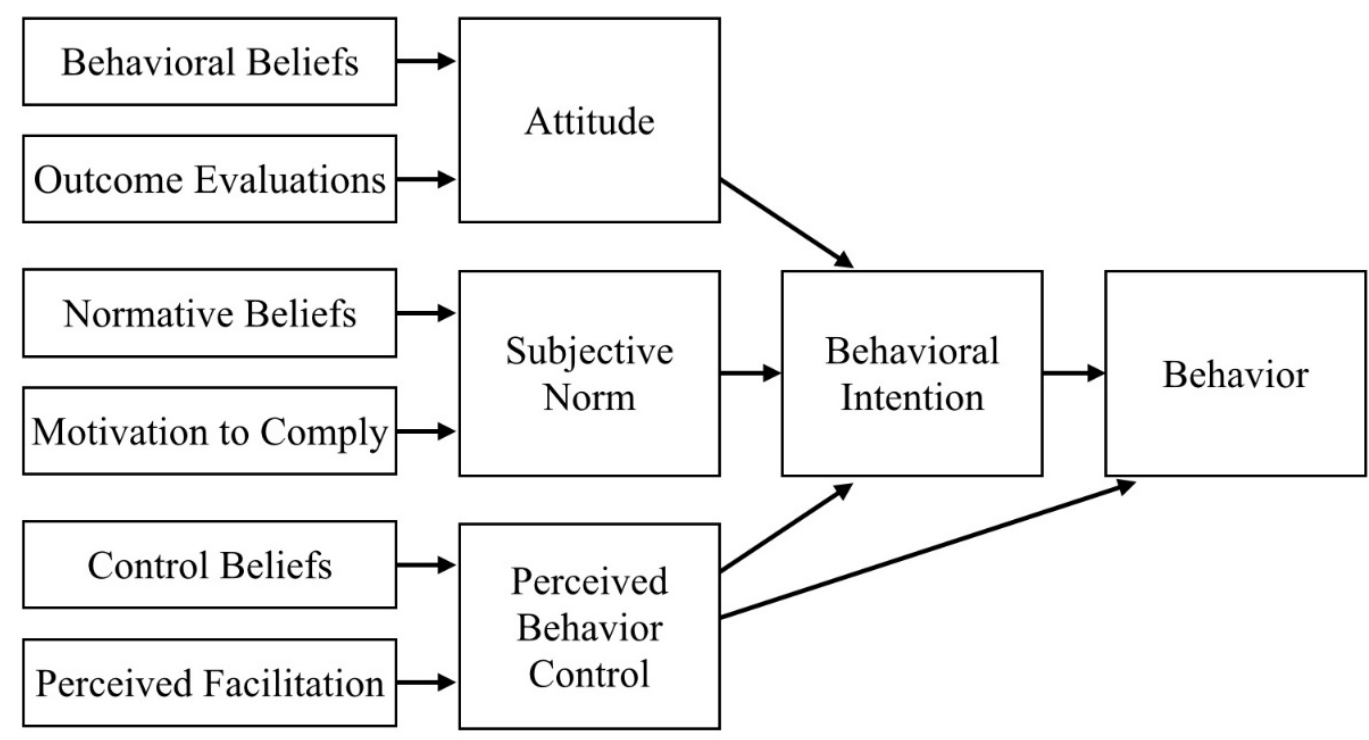

Figure 1. Model of the TPB (Ajzen, 1989)

Ajzen (1988) still argues that attitude and subjective norms can impact a person's behavioral intention. The attitude to perform a certain behavior is constituted by two subcategories: the perceived consequences of following through with action and an evaluation of those consequences. Subjective norms refer to the perceived expectation to perform the behavior from other individuals, as well as the pressure to perform the act from others. The TPB adds a function not identified in the TRA known as perceived behavior control. This function accounts for the personal levels of confidence in performing the behavior. This study will be basing a major part of its research on this particular function. Perceived behavior control can be further described by reviewing Bandura's (1977, 1986, 1989) work on self-efficacy.

Self-efficacy. Initially, Bandura (1977) introduced self-efficacy in his development of the framework for social cognitive theory, originally known as Social 
Learning Theory. Bandura (1977) first described self-efficacy as an individual's ability to generate desired behaviors to produce an outcome. The definition eventually broadened to include people's beliefs concerning their abilities to actively influence a situation that affects their life (Bandura, 1989). Furthermore, self-efficacy scholars do not specifically analyze a person's skills but the cognitive judgments or confidences produced to perform a behavior. Research suggests that there is a strong relationship between people's motivation and the actual skills they possess to execute a behavior. Thus, a person's internal judgment regarding her or his capabilities to perform a specific behavior impacts how the individual will approach an activity, how much time she or he will spend executing the activity, and how long the person will endure despite aversive responses to the behavior (Bandura, 1977, 1986; Bandura \& Wood, 1989).

Self-efficacy expectancies will fluctuate along three dimensions of efficacy: magnitude, strength, and generality (Bandura, 1977, 1986, 1989). Magnitude refers to a cognitive organization of behaviors by the level of difficulty to perform. Strength focuses on the individual's belief that they can perform the behavior. Generality refers to how a person internally compares and generalizes his or her self-efficacy expectations from one situation to another similar situation. While the three dimensions are necessary to thoroughly understand self-efficacy expectancies, the majority of scholars present a onedimensional expectancy approach that reflects the strength dimension (Maddux, 1995).

Bandura (1977) theorized that perceived self-efficacy affects one's decisionmaking, work ethic, and determination. Essentially, an individual's confidence in personal abilities correlates to the possible accomplishment of the task. Bandura (1997) proposes four key sources of self-efficacy: enactive mastery experiences, vicarious 
experiences, social persuasion, and physiological and affective states. These four main influences do not affect every individual the same way and are primarily used as guidelines to help measure efficacy. Schunk (1991) also notes that "self-efficacy is not the only influence on behavior; it is not necessarily the most important" (p. 209). However, while there are other factors that contribute to an individual's behavior, this does not detract from the notion that self-efficacy can have a major influence in decisionmaking and perception. Bandura (1986) considered self-reflection the most unique human capability, for through this form of self-referent thought, people evaluate and alter their own thinking and behavior.

When examining self-efficacy in educational settings, studies have shown that academics affect a student's self-efficacy. Initially, self-efficacy can be developed through mastery experiences (Bandura, 1997). Bandura (1997) presents accounts that when individuals perform successfully during a task, their sense of self-efficacy increases. Additionally, Schunk (1991) concludes that "people who have a low sense of efficacy for accomplishing a task may avoid it; those who believe they are capable should participate readily" (p. 208). Furthermore, a person's ability to manage and overcome failing a task helps reinforce a person's preconceived efficacies. Efficacy is increased through success and lowered through failure (Bandura, 1986).

While completing and succeeding in a task does indicate that an individual's selfefficacy will increase, there are other possible factors that could influence their perception. While the first influencer is primarily affected by an internal response, the other three sources of self-efficacy have more external elements. Initially, observing another individual successfully complete a task can increase one's self-efficacy. Through 
the use of vicarious experiences, the individual experiences a social model of success or failure as that observation increases the observer's belief that he or she, too, can successfully complete that task (Bandura, 1997). Bandura notes that the more an individual can relate to the situation observed (e.g., personal, situational), the more an individual is inclined to believe he or she will succeed or fail. Individuals seek examples of successful completion of tasks they wish to achieve themselves. Another way an individual's self-efficacy is strengthened is through social persuasion. People who are verbally persuaded that they possess the capabilities to master given activities are more likely to make a greater effort and sustain it than if they harbor self-doubts and dwell on personal deficiencies when problems arise (Bandura, 1997). If reasonable and plausible expectations are presented before the individual, their self-efficacy increases, once the person is presented with feedback applying to her or his capabilities. A simple accolade typically does not help a person's belief in her or his capabilities. It is more difficult to instill high beliefs of personal efficacy by social persuasion alone than to undermine it (Bandura, 1997). The last influencer relies on psychological responses to the situation. A person's moods, feelings, and physical response can play a role in influencing his or her abilities. Apprehension and internal or external interference can invoke beliefs that the individual will fail. It is not the sheer intensity of emotional and physical reactions that is important, but rather how these are perceived and interpreted the situation (Bandura, 1997).

Additionally, Bandura (1993) proposes that there are three different levels at which self-efficacy operates to impact the academic development of students: (1) Students' beliefs in their own efficacy, (2) level of motivation, and (3) academic 
accomplishments. Bandura states that collective instructional self-efficacy can positively contribute academic success within the entire school. Students continually interact with other students, instructors, professors, and faculty, which constantly provoke them to reexamine their sense of self.

\section{Research Questions}

Past literature describes the connection between people's beliefs and their behaviors. The TPB framework offers insight into how individuals' perceived ability could influence their actions. People's attitudes, norms and self-efficacy are important indicators of future decisions.

Initially, the current study examines the process in which students come in contact with civic and political engagement concepts. Past literature (e.g., Colby et al., 2007) reveals that students are mainly taught either actively (two-way teaching) or passively (one-way teaching). Furthermore, these types of interactions can impact students' behavioral outcomes. Some research suggests that active learning should have more of an impact on civic and political engagement outcomes (Colby et al., 2007); however, more research is needed to further support this claim. The first research question, a through c, explores the communication process in the classroom:

$\mathrm{RQ}_{1}$ : Does the type of classroom communication (one-way v. two-way) predict civic and political engagement outcomes?

$\mathrm{RQ}_{1 \mathrm{a}}$ : Does the type of classroom communication (one-way v. two-way) predict attitudes towards civic and political engagement?

$\mathrm{RQ}_{1 b}$ : Does the type of classroom communication (one-way v. two-way) predict self-efficacy towards civic and political engagement? 
$\mathrm{RQ}_{10}$ : Does the type of classroom communication (one-way v. two-way)

predict behavioral intentions towards future civic and political engagement?

Research question one is the basis for this study because it introduces the communication relationship between education and students. The study attempts to generate results to describe the variety of ways students come into contact with civic and political engagement curriculum, as well as begins to provide content defining how attitudes, selfefficacy, and future behavioral intentions toward engagement relate to the classroom communication process.

These communication processes (e.g., one-way teaching, two-way teaching) regarding civic and political engagement could help develop current behavior within students, which in turn could impact their future intentions towards engagement. Past studies (e.g., Colby et al., 2007) suggest that civic and political engagement instruction can impact a person's feelings about volunteering, voting, or being civically engaged. Therefore, the following question is proposed regarding behavior toward future civic engagement:

$\mathrm{RQ}_{2}$ : Does the linear combination of attitudes, norms, and self-efficacy predict intent toward future civic and political engagement?

The link from classroom communication to behavioral outcomes (i.e., attitudes, norms, and self-efficacy) to future intentions, demonstrates a potential system of how students are receiving and interpreting information, specifically regarding civic and political engagement. It is crucial to study each part of this proposed system to better explain impact of classroom communication on individuals. 
The average college or university student encounters a variety of classroom situations (e.g., lectures, discussions, or assignments) on a daily basis that could impact current and future behaviors. Furthermore, students may be exposed to the same information in multiple classes. Colleges and universities have begun to develop solutions to integrate civic and political engagement concepts more into courses across all academic schools. These strategies could give students more of an opportunity to be exposed to civic and political engagement concepts throughout their college career, leading to impacts on their behavior. Thus, the next research questions enquire:

$\mathrm{RQ}_{3}$ : Does the amount of classroom exposure to civic and political engagement predict students' self-efficacy for civic and political engagement?

$\mathrm{RQ}_{4}$ : Does the amount of classroom exposure to civic and political engagement predict students' intent toward future civic and political engagement?

These research questions attempt to identify the relationship between exposure and behavior. This relationship can be supported by studies (Fang, Singh, \& Ahluwalia, 2007; Harmon-Jones \& Allen, 2001; Lehnert, Till, \& Carlson, 2013; Zajonc, 2001) that examine the mere-exposure phenomenon, a theory commonly used to analyze advertising and marketing material. Mere-exposure contends that the more exposure individuals have to a subject (e.g., a brand, advertisement, or an issue), the more individuals will develop preferences or opinions toward the subject (Zajonc, 1968). Additionally, the theory reiterates the concept that frequent exposure is typically required for individuals to learn or be conditioned to a particular subject (Harmon-Jones \& Allen, 2001). Although this study focuses on civic and political engagement in the classroom, the researcher suggests 
that the characteristics of the mere-exposure effect bolster the importance of identifying and analyzing the third and fourth research question.

At the same time, despite colleges and universities' incorporation of civic and political engagement curriculum, there could be a fatigue effect regarding the amount of exposure to civic and political engagement concepts in the classroom. Scholars (Danaher, 1996; Greyser, 1973; Simon, 1982) argue that as much as repetition can have a positive influence to behavior and perception, it can also have an adverse effect. In relationship to the mere-exposure phenomenon, the fatigue effect refers to the process of individuals becoming disinterested in a subject due to its repetitive exposure (Calder \& Sternthal 1980; Grass \& Wallace, 1969; Naik, Mantrala, \& Sawyer, 1998; Weilbacher, 1970). Moreover, if the message is weak or the subject does not elicit a strong emotional or rational appeal to individuals, the potential for fatigue within individuals is greater (Bass, Bruce, Majumdar, \& Murthi, 2007; Berlyne, 1970). The fatigue or boredom toward a particular subject is directly related to the final research question, which asks:

$\mathrm{RQ}_{5}$ : Is there a curvilinear relation between civic engagement exposure in the college classroom and future intent to engage in civic engagement activities? While scholars have primarily applied the fatigue effect to studying advertisements, this research can also be used as a foundation to explore fatigue involving civic and political engagement. Scholars have yet to significantly explore possible exposure fatigue toward civic and political engagement. While past studies have sought to figure out ways to expand the incorporation of civic and political engagement in course curriculum throughout colleges or universities, it is crucial that researchers examine any potential negative effects due to overexposure of civic and political engagement integration. The 
current study attempts to expand the body of literature regarding this possible phenomenon.

\section{Conclusion}

Based on the review of literature, it is apparent that more research and tests should investigate how what happens in a classroom affects a student's self-efficacy for civic engagement. An instructor is one of the key members at the threshold of influencing young individuals to see society from a particular perspective. Therefore, this study seeks to better understand the affect an instructor has on a student's sense of value on social issues. 


\section{CHAPTER II}

\section{METHODS}

The intent of this study is to examine the relationship between civic engagement education and civic engagement attitudes. This chapter describes the process of operationalizing each variable mentioned in the review of literature in order to answer the five research questions. The chapter will provide specific detail about the participants, instruments, procedure, and statistical analyses.

\section{Participants}

A sample was obtained by enlisting students enrolled at a large Midwestern university. The participants were solicited through campus lists of individuals attending the university. An invitation to participate in the survey was distributed to a random selection of students at a large Midwestern university who had agreed to receive such invitations through their standard university e-mail account. Students willing to participate clicked the link within the e-mail to be directed to the survey.

A total of 251 graduate and undergraduate students completed the survey. Specifically, there were 154 female participants, 91 male participants, 2 participants that chose "other," and 4 that chose not to answer. The mean age of the participants was 23.91 years of age $(S D=8.60)$, with a range from 18 to 65 years old. The participants reported a mean political view average of $5.79(S D=2.28)$, with a range from 1.00 (very 
conservative) to 10.00 (very liberal) on a 10.00 scale. Based on the participants who responded, the largest group of participants identified themselves as graduate student (26.80\%), followed by freshmen (25.30\%), juniors (19.20\%), senior (17.60\%), and sophomores (6.90\%). The majority of participants identified their major in the College of Arts and Sciences (44.00\%), followed by College of Applied Sciences and Technology (17.7\%\%), College of Business (15.30\%), College of Education (11.70\%), College of Fine Arts (5.60\%), College of Agriculture (2.80\%), College of Nursing (2.00\%), and College of Architect and Engineering (0.80\%). Participants took an average of 4.88 classes that incorporated community issues, politics, or volunteerism into the course ( $S D$ $=2.28$ ), with a range from 1 to 34 classes. Overall, the participants predominately identified themselves as Caucasian/white (80.00\%), followed by Black/African American (6.80\%), Hispanic/Latino (6.40\%), Asian/Pacific Islander (6.40\%), and American Indian $(.40 \%)$.

\section{Data Collection}

\section{Instrument}

A quantitative research design was implemented to discover how learning experiences regarding civic engagement in the classroom impact students' attitudes, selfefficacy, and intent to be civically engaged in the future. Specifically, all participants accessed the survey through an on-line survey site. The current survey utilized existing scales: two subscales from the political engagement project scale (Colby et al., 2007), a subjective norms measure, an attitude measure, and a behavioral intention measures (Bruckner, 2011). Additionally, participants answered eight demographic questions 
regarding sex, age, race, political view, number of classes, year in school, major, and academic college.

The Political Engagement Project (PEP) scale utilizes a variety of survey questions and measures to investigate the impact of educational efforts on college students' civic engagement, political engagement, and service-learning development. The current study employed two sections from the PEP scale: the course activities scale and the self-efficacy scale. The original course activities scale, developed by Colby et al. (2007), employs responses ranging from 1 (not important) to 6 (very important). Colby et al. reported reliabilities for three subscales of this measure: enhanced academic learning for political engagement ( $\alpha=.73)$, political engagement in the community $(\alpha=.81)$, and political experience in the classroom $(\alpha=.69)$. Example items of the course activities scale include "assigned readings about politics, community issues, or volunteering" and "required participation in a service-learning project or volunteering." The current study condensed the scale to 9 items that included the subcategories of whether instruction was passive learning (e.g., lectures, readings) or active learning (e.g., discussion, out-of-class participation). More specifically, active and passive learning was operationalized based on the descriptions provided in the review of literature. The researcher filtered each into the two categories. In this study, survey questions 2,7 , and 8 were consider to be passive learning techniques, while $3,4,5,6$, and 9 were determined to be traits of active learning. The researcher utilized a 5-point Likert-type coding system to create consistency throughout the survey.

Additionally, the 12-item self-efficacy subscale, developed by Colby et al. (2007), originally employed responses ranging from 1 (not at all easy) to 6 (very easy), 
measuring three subcategories: efficacy in political institution contexts (Colby et al.'s reliability: $\alpha=.76)$, efficacy in community context $(\alpha=.81)$, and efficacy in campus context $(\alpha=.68)$. Items ask participants about how much they feel that they can impact things such as "getting potholes in your streets repaired," "influencing decisions about who teaches on your campus," and "starting an after school program for children whose parents work." The current study condensed the scale to 10 items, with a 5-point Likerttype coding system to create consistency throughout the survey. As the researcher in this case is not interested in specific aspects of self-efficacy, the scale was treated as a single measure. Additionally, it is important to note that when the survey was presented to participants, they were unintentionally presented with different response options ranging from 1 (extremely not effective) to 5 (extremely effective). While the researcher verified that participants' responses correlated with predicted responses, this inadvertent modification may have skewed the overall results of the current study.

The current study also employed scales that measure subjective norms, attitudes, and behavioral intention developed by Bruckner (2011). The subjective norms scale was constructed to analyze college students' normative beliefs to comply with a referent. The survey consists of 20 items that identify the participants' relationship to four referents: parents, closest friends, admired individuals, and teachers. Participants identified the amount of motivation to comply to each referent, for instance, "When it comes to matters of political engagement, I want to do what my parents [closest friends, etc.] think I should do." Instead of employing 20 items for this scale, this current study used 16 items on a 5point scale (strongly disagree to strongly agree). Cronbach's alpha for the subjective norm scale was strong $(\alpha=.92)$. 
The next scale used for this study is the attitudes measure. The scale, recently developed by Bruckner (2011), contains eight items that examine attitudes to engage in civic and political behaviors. The attitudes scale, employing a responses ranging from 1 (strongly disagree) to 5 (strongly agree), produced two Cronbach's alphas: belief strength $(\alpha=.63)$ and belief evaluation $(\alpha=.72)$. The present study maintained all aspects of the scale to analyze political and civic engagement attitudes. "It is good to be an effective participant in political engagement activities," "It is good to understand my own opinions," and "It is good to help the community" are examples of items on this scale.

The final scale used for this study is the Behavioral Intention Measures (BIM). The scale, developed by Bruckner (2011), contains 23 items that examine intentions to engage in civic behaviors. Modified from a political and civic involvement measure by Colby et al. (2007), the BIM produced a reliability of .92 in the Bruckner study. This measure uses a 5-point scale ranging participants' current intentions toward civic engagement from never to very often. The present study modified the scale to analyze future civic engagement intentions after college. "Volunteer for a community organization" is an example of an item on this scale.

\section{Procedure}

The survey was posted through Select Survey, a protected online survey system. The survey used students enrolled at a Midwestern university as the sample. Individuals received an e-mail inviting them to participate in the survey. To ensure participants' anonymity and privacy, the survey did not request names or any information that would reveal their identity, and the researcher did not track participants' IP addresses. Once 
participants received the invitation e-mail, they were able to log on to the survey from any Internet connection, over a period of three weeks during which the survey remained open. After first receiving a screen with their participant rights, participants who indicated that they were at least 18 and wished to continue were directed to the survey. The survey took an average of 10 to 15 minutes to complete.

\section{Data Analysis}

After collecting the completed surveys, the researcher used IBM Statistical Package for the Social Sciences (SPSS) 22 to analyze the numerical data from the survey. As no measure contained negatively worded items, no items were reverse coded. The researcher summed items from each measure to create single variables.

The researcher first added the following items together to create single measures for one-way teaching $(2,7, \& 8)$ and interactive teaching $(3,4,5,6, \& 9)$. Based on the strength of each of the borrowed scales, an exploratory factor analysis (EFA) was not conducted to verify the structural integrity of the scale. Then, the researcher added together scale items as noted above to create single scores for the civic and political engagement self-efficacy, civic and political engagement attitudes, and civic and political engagement intent measures.

To address the first research question, the researcher ran a multiple regression to determine how one-way and two-way teaching predict attitudes towards civic and political engagement $\left(R Q_{1 a}\right)$, self-efficacy towards civic and political engagement $\left(R Q_{1 b}\right)$, and behavioral intentions towards future civic engagement $\left(\mathrm{RQ}_{1 \mathrm{c}}\right)$.

To test $\mathrm{RQ}_{2}$, a multiple linear regression model was calculated. Multiple regression provides data for researchers to determine among several variables, which 
variable accounts for the most variance; that is, the greatest ability to predict the measure of another variable. In this study, employing a multiple regression test determined whether intent for future civic engagement would best be predicted by civic engagement attitudes, civic engagement norms, or civic engagement self-efficacy $\left(\mathrm{RQ}_{2}\right)$.

Next, a simple regression was run to address research questions three and four. A regression analysis examined how the amount of classroom exposure to civic and political engagement predicts students' self-efficacy for civic engagement, as well as the amount of classroom exposure to civic engagement predicts students' behavioral intentions toward future civic engagement. Lastly, a curve estimation regression procedure was conducted, testing for cubic and quadratic relations to address research question five. This test was used to indicate if there is a curvilinear relation between civic engagement exposure in the college classroom and future intent to engage in civic engagement activities. For all research tests, alpha will be set to .05 .

\section{Conclusion}

Combining scales to create one questionnaire, the survey provided the necessary data to acquire a better understand the impacts of teaching civic and political engagement in a university classroom setting. This chapter presented a detailed explanation of the participants, instruments, procedure, and analyses used for this current study. The next chapter will report the findings based on these methods. 


\section{CHAPTER III}

\section{RESULTS}

The previous chapter described the methods used to test the five research questions for the study. Specifically, the previous chapter presented a description of the participants, the process of collecting the data, and the procedure to analyze the data in order to produce results. The current chapter discloses the statistical results obtained through the data collection and analysis processes. Results were calculated using SPSS. This data provided outcomes to answer of each research questions in this study.

\section{Results Summary}

The overall intent of the current study is to investigate the relationships between education and engagement in the community both civically or politically. To accomplish this objective, multiple well-founded scales were employed to produce reliable results. The researcher calculated reliabilities for each scale. While an alpha of .65 to .70 is considered minimally acceptable, a respectable coefficient alpha for a scale is .70 to .80, a very good alpha is .80 to .90 , and an excellent alpha is .90 or above for a short scale (DeVellis, 2003). In this study, the One-Way Teaching scale $(\alpha=.71)$ and the Two-Way Teaching scale $(\alpha=.77)$ are respectable reliabilities. The Classroom Exposure scale $(\alpha=$ $.86)$, the Self-Efficacy scale $(\alpha=.83)$, the Attitudes scale $(\alpha=.83)$, and the Subjective 
Norms scale $(\alpha=.85)$ each produced very good Cronbach's alpha coefficient reliabilities, while the Behavioral Intentions scale $(\alpha=.92)$ generated an excellent alpha.

\section{Teaching Predicting Future Engagement}

Research question one, examined how one-way teaching or two-way teaching contributed to predicting civic and political engagement. The first part of research question one served to explore the types of teaching that predict attitude towards future civic and political engagement. A multiple linear regression procedure investigated whether students' Attitudes towards civic engagement could be predicted by the linear combination of One-Way Teaching and Two-Way Teaching. Missing cases were excluded pairwise. Results of the regression model indicated that $5.1 \%$ of the variance in Attitudes could be predicted by One-Way Teaching and Two-Way Teaching, $R_{a d j}^{2}=.043, F(2,248)$ $=6.653, p<.01$. Results indicated that predictor variables were able to account for a significant amount of variance in the outcome variable. Analysis of regression coefficients indicated that One-Way Teaching, $\beta=.229, t=2.175, p<.05$ was a significant predictor, and Two-Way Teaching, $\beta=-.004, t=-.034, p=.973$, was not a significant predictor of Attitudes. Squared part correlations revealed that One-Way Teaching uniquely predicted $1.8 \%$ of the variance and Two-Way Teaching did not uniquely predict any of the variance. Neither variable produced TOL or VIF statistics indicating collinearity. Beta weights can be found in Table 1. 
Table 1

Beta Weights for One-Way and Two-Way Teaching on Attitudes towards Civic Engagement

\begin{tabular}{lcccc}
\hline \multicolumn{1}{c}{ Predictor Variables } & & $B$ & $S E B$ & $\beta$ \\
\hline One-Way Teaching & & .141 & .065 & .229 \\
Two-Way Teaching & & -.002 & .073 & -.004 \\
& $R^{2}$ & .051 & \\
& $R^{2}{ }_{\text {adj }}$ & & .043 & \\
& $F$ & 6.653 &
\end{tabular}

Note. An * indicates a unique significant predictor variable at $p<.05 .(n=251)$

The second part of research question one sought to explore the types of teaching that better predict self-efficacy towards civic and political engagement. A multiple linear regression procedure investigated whether students' Self-Efficacy towards civic engagement could be predicted by the linear combination of One-Way Teaching and Two-Way Teaching. Missing cases were excluded pairwise. Results of the regression analysis indicated that $8.2 \%$ of the variance in Self-Efficacy could be predicted by OneWay Teaching and Two-Way Teaching, $R_{a d j}^{2}=.075, F(2,248)=11.145, p<.001$. Results indicated that predictor variables were able to account for a significant amount of variance in the outcome variable. Analysis of regression coefficients indicated that neither One-Way Teaching, $\beta=.111, t=1.074, p=.284$, nor Two-Way Teaching, $\beta=$ $141, t=1.839, p=.067$, was a significant individual predictor of Self-Efficacy. Squared part correlations revealed that One-Way Teaching uniquely predicted $0.004 \%$ of the 
variance and Two-Way Teaching uniquely predicted $0.013 \%$ of the variance. Neither variable produced TOL or VIF statistics indicating collinearity. Beta weights can be found in Table 2.

Table 2

Beta Weights for One-Way and Two-Way Teaching on Self-Efficacy towards Civic Engagement

\begin{tabular}{lcccc}
\hline \multicolumn{1}{c}{ Predictor Variables } & $B$ & $S E B$ & $\beta$ \\
\hline One-Way Teaching & & .072 & .068 & .111 \\
Two-Way Teaching & & .141 & .077 & .190 \\
& $R^{2}$ & & .082 & \\
& $R^{2}{ }_{\text {adj }}$ & & .075 & \\
& $F$ & & 11.145
\end{tabular}

Note. An * indicates a unique significant predictor variable at $p<.05 .(n=251)$

The third and final part of research question one posed to explore the types of teaching that predict behavioral intention towards future civic and political engagement. A multiple linear regression procedure investigated whether students' Behavioral Intention towards future civic engagement could be predicted by the linear combination of One-Way Teaching and Two-Way Teaching. Missing cases were excluded pairwise. Results of the regression analysis indicated that $9.6 \%$ of the variance in Attitudes could be predicted by One-Way Teaching and Two-Way Teaching, $R_{\text {adj }}^{2}=.088, F(2,246)=$ $12.994, p<.05$. Results indicated that predictor variables were able to account for a 
significant amount of variance in the outcome variable. Analysis of regression coefficients indicated that neither One-Way Teaching, $\beta=.199, t=1.930, p=.055$, and Two-Way Teaching, $\beta=.125, t=1.218, p=.224$, were significant predictors of Behavioral Intention. Squared part correlations revealed that One-Way Teaching uniquely predicted $1.4 \%$ of the variance and Two-Way Teaching uniquely predicted $0.55 \%$ of the variance. Beta weights can be found in Table 3.

Table 3

Beta Weights for One-Way and Two-Way Teaching on Behavioral Intention towards Future Civic Engagement

\begin{tabular}{lcccc}
\hline \multicolumn{1}{c}{ Predictor Variables } & $B$ & $S E B$ & $\beta$ \\
\hline One-Way Teaching & & .145 & .075 & .199 \\
Two-Way Teaching & .104 & .085 & .125 \\
& $R^{2}$ & & .096 & \\
& $R^{2}{ }_{a d j}$ & & .088 & \\
& $F$ & & 12.994 &
\end{tabular}

Note. An * indicates a unique significant predictor variable at $p<.05 .(n=251)$

Post-hoc independent samples t-tests. A post-hoc analysis was conducted to assist in further explaining the results of research question one, a through $\mathrm{c}$. To follow up the multiple regression model, three separate independent samples $t$-tests were conducted to see if self-efficacy, attitudes, and behavioral intention changed from freshmen year to senior year. The following paragraphs present the scores of the three criterion variables, 
as well as the significant differences between freshmen and seniors. Table 4 shows combined results from the $t$-tests.

The first independent samples $t$-test was calculated to compare the mean scores of Freshmen and Seniors on Self-efficacy. Freshmen participants scores for self-efficacy $(M$ $=3.36, S D=.733, n=63$ ) were not significantly different from those of Senior participants $(M=3.18, S D=.539, n=42 ; t(103)=1.35, p=.084)$. The $95 \%$ confidence interval on the difference between means extends from -.084 to .440 .

Next, an independent samples $t$-test was calculated to compare the mean scores of Freshmen and Seniors on Attitudes. Freshmen participants had lower mean scores for Attitudes $(M=3.84, S D=.709, n=64)$ than did Senior participants $(M=4.20, S D=$ $0.492, n=45)$, a difference that was significant $(t(107)=-2.91, p=.069)$. The $95 \%$ confidence interval on the difference between means extends from -.598 to -.113.

The last independent samples $t$-test was calculated to compare the mean scores of Freshmen and Seniors on Behavioral Intentions toward Future Civic Engagement. Mean scores for Freshmen participants for Behavioral Intention $(M=3.01, S D=.716, n=62)$ were not significantly different from those of Senior participants $(M=3.36, S D=.740, n$ $=41 ; t(101)=-2.38, p=.381)$. The $95 \%$ confidence interval on the difference between means extends from -.638 to -.058 . 
Table 4

Results of Independent t-Tests on Self-Efficacy, Attitudes, and Behavioral Intention by Year in School

\begin{tabular}{|c|c|c|c|c|c|c|c|c|}
\hline \multirow[t]{3}{*}{ Outcome } & \multicolumn{6}{|c|}{ Group } & \multirow[b]{3}{*}{$t$} & \multirow[b]{3}{*}{$d f$} \\
\hline & \multicolumn{3}{|c|}{ Freshmen } & \multicolumn{3}{|c|}{ Seniors } & & \\
\hline & $M$ & $S D$ & $n$ & $M$ & $S D$ & $n$ & & \\
\hline Self-efficacy & 3.36 & .733 & 63 & 3.18 & .539 & 42 & 1.35 & 103 \\
\hline Attitudes & $3.84^{*}$ & .709 & 64 & $4.20 *$ & .492 & 45 & -2.91 & 107 \\
\hline Behavioral & 3.01 & .716 & 62 & 3.36 & .740 & 41 & -2.38 & 101 \\
\hline
\end{tabular}

Note. An $*$ indicates a significant difference at $p<.05$. The $t$-test results explored selfefficacy and attitudes towards current civic or political engagement, while behavioral intention investigated future engagement.

\section{Attitudes, Norms, and Self-Efficacy Predicting Engagement}

The second research question sought to understand how attitudes, norms, and selfefficacy predicted future civic engagement. A multiple linear regression procedure investigated whether students' intent toward Future Civic Engagement could be predicted by the linear combination of Attitudes, Norms, and Self-Efficacy. Missing cases were excluded pairwise. Results of the regression analysis indicated that $35.9 \%$ of the variance in Future Civic Engagement could be predicted by Attitudes, Norms, and Self-Efficacy, $R_{a d j}^{2}=.351, F(3,247)=46.123, p<.001$. Results indicated that predictor variables were able to account for a significant amount of variance in the outcome variable. Analysis of regression coefficients indicated that Attitudes, $\beta=.308, t=5.123, p<.01$, Norms, $\beta=$ 
$.279, t=4.567, p<.001$, and Self-Efficacy, $\beta=.224, t=4.300, p<.001$, were all significant individual predictors of Future Civic Engagement. In sequential order, Attitudes is a strong positive predictor, followed by Norms, and finally Self-Efficacy. Squared part correlations revealed that Attitudes uniquely predicted $6.8 \%$ of the variance, Norms uniquely predicted $5.4 \%$ of the variance, and Self-Efficacy uniquely predicted $4.8 \%$ of the variance. Neither variable produced TOL or VIF statistics indicating collinearity. Beta weights can be found in Table 5 .

Table 5

Beta Weights for Attitudes, Norms, and Self-Efficacy on Future Civic Engagement

\begin{tabular}{lcccc}
\hline \multicolumn{1}{c}{ Predictor Variables } & $B$ & SE B & $\beta$ \\
\hline *Attitudes & & .364 & .071 & .308 \\
*Norms & & .357 & .078 & .279 \\
*Self-Efficacy & & .250 & .058 & .224 \\
& $R^{2}$ & & .359 & \\
& $R^{2}{ }_{\text {adj }}$ & & .351 & \\
& $F$ & & 46.123 & \\
\hline
\end{tabular}

Note. $\mathrm{An} *$ indicates a unique significant predictor variable at $p<.05 .(n=251)$. The Attitudes scale $(\alpha=.84)$, the Norms scale $(\alpha=.85)$, and the Self-Efficacy scale $(\alpha=.83)$ each produced excellent Cronbach's alpha coefficient reliabilities.

\section{Classroom Exposure Predicting Self-Efficacy}

The third research question of this study posed to examine how the amount of classroom exposure contributes to the prediction of self-efficacy for civic and political 
engagement. A simple regression procedure investigated if students'Self-Efficacy for civic and political engagement could be predicted by the amount of Classroom Exposure. Missing cases were excluded pairwise. Results of the regression analysis indicated that $0.6 \%$ of the variance in Self-Efficacy could be predicted by Classroom Exposure, $R_{\text {adj }}^{2}=$ $.002, F(1,249)=1.391, p>.05$. However, the results indicated that Classroom Exposure was not significantly able to account for variance in Self-Efficacy. Analysis of regression coefficients indicated that Self-Efficacy, $\beta=.075, t=1.179, p=.239$, was not a significant predictor. Beta weights can be found in Table 6 .

Table 6

Beta Weights for Self-Efficacy for Civic Engagement on Classroom Exposure

\begin{tabular}{lcccc}
\hline & Variable & $B$ & $S E B$ & $\beta$ \\
\hline Self-Efficacy & & .008 & .007 & .075 \\
& $R^{2}$ & & .006 & \\
$R^{2}{ }_{\text {adj }}$ & & .002 & \\
$F$ & & 1.391 &
\end{tabular}

Note. An $*$ indicates a unique significant predictor variable at $p<.05 .(n=251)$

\section{Classroom Exposure Predicting Behavioral Intent}

Research question four examined how the amount of classroom exposure to civic and political engagement concepts contributes to predicting behavioral intent toward future civic and political engagement. A simple regression procedure investigated whether students' Behavioral Intent toward Future Civic Engagement could be predicted 
by the amount of Classroom Exposure. Missing cases were excluded pairwise. Results of the regression analysis indicated that $6.4 \%$ of the variance in Behavioral Intent toward Future Civic Engagement could be predicted by Classroom Exposure, $R_{a d j}^{2}=.060, F(1$, $248)=16.841, p<.001$. Thus, the significant results indicated that Classroom Exposure was able to account for a significant amount of variance in Future Civic Engagement. Analysis of regression coefficients indicated that Behavioral Intent toward Future Civic Engagement, $\beta=.252, t=4.104, p<.001$, was a significant predictor. Beta weights can be found in Table 7 .

Table 7

Beta Weights for Intent toward Future Civic Engagement on Classroom Exposure

$\begin{array}{llll}\text { Variable } & B & S E B & \beta\end{array}$

*Intent toward

Future Civic Engagement

.007

$$
\begin{array}{r}
R^{2} \\
R_{a d j}^{2} \\
F
\end{array}
$$$$
.064
$$$$
.060
$$

Note. $\mathrm{An} *$ indicates a unique significant predictor variable at $p<.05 .(n=251)$

\section{Curvilinear Relationship between Engagement Exposure and Behavioral Intent}

The fifth and final research question studied the curvilinear relationship between exposure to civic and political engagement concepts and intentions for future engagement. To successfully accomplish this investigation, a curve estimation regression 
procedure was used to examine the variables. The results presented data for linear, cubic, quadratic, growth, and exponential. The five tests are crucial to investigating curvilinear relations. The results for each test will be presented in the following paragraphs.

Linear. Results from the linear testing portion of the curve estimation regression analysis indicated that $7 \%$ of the variance in future Behavioral Intentions could be predicted by Civic Engagement Exposure, $R_{a d j}^{2}=.066, F(1,228)=17.027, p<.001$. Missing cases were excluded pairwise. Thus, the significant results of the regression procedure indicated that future Behavioral Intentions were able to account for a significant amount of variance in Civic Engagement Exposure. Analysis of regression coefficients indicated that Civic Engagement Exposure, $\beta=.264, t=4.126, p<.001$, was a significant predictor. Beta weights can be found in Table 8 .

Table 8

Linear - Beta Weights for Behavioral Intention on Engagement Exposure

\begin{tabular}{|c|c|c|c|c|}
\hline Variable & & $B$ & $S E B$ & $\beta$ \\
\hline \multirow[t]{4}{*}{ *Civic Engagement Exposure } & & .032 & .008 & .264 \\
\hline & $R^{2}$ & & .070 & \\
\hline & $R_{a d j}^{2}$ & & .066 & \\
\hline & $F$ & & 17.027 & \\
\hline
\end{tabular}

Note. An * indicates a unique significant predictor variable at $p<.05 .(n=251)$

Quadratic. Quadratic testing results indicated that $7.2 \%$ of the variance in future Behavioral Intentions could be predicted by Civic Engagement Exposure and Civic 
Engagement Exposure $* * 2, R_{a d j}^{2}=.063, F(2,226)=8.718, p<.001$. Missing cases were excluded pairwise. Results of the regression indicated that predictor variables were able to account for a significant amount of variance in the outcome variable. Analysis of regression coefficients indicated that Civic Engagement Exposure, $\beta=.370, t=2.168, p$ $<.05$ was a significant predictor, but Civic Engagement Exposure $* * 2, \beta=-.115, t=-$ $.671, p=.503$ was not a significant predictor of future Behavioral Intentions. Beta weights can be found in Table 9.

Table 9

Quadratic - Beta Weights for Behavioral Intention on Engagement Exposure

\begin{tabular}{lcccc}
\hline \multicolumn{1}{c}{ Predictor Variables } & & $B$ & $S E B$ & $\beta$ \\
\hline *Civic Engagement Exposure & & .045 & .021 & .370 \\
Civic Engagement Exposure**2 & & -.001 & -.001 & -.115 \\
& $R^{2}$ & .072 & \\
& $R^{2}{ }_{\text {adj }}$ & & .063 & \\
& $F$ & & 8.718 &
\end{tabular}

Note. An $*$ indicates a unique significant predictor variable at $p<.05 .(n=251)$

Cubic. Cubic results of the curve estimation regression analysis indicated that $7.6 \%$ of the variance in future Behavioral Intentions could be predicted by Civic Engagement Exposure, Civic Engagement Exposure**2, and Civic Engagement Exposure $^{* * 3}, R_{\text {adj }}^{2}=.064, F(2,226)=6.154, p<.001$. Missing cases were excluded pairwise. Results of the regression indicated that predictor variables were able to account 
for a significant amount of variance in the outcome variable. However, in analysis of specific effects, regression coefficients indicated that neither Civic Engagement Exposure, $\beta=.079, t=.235, p=.815$, Civic Engagement Exposure ${ }^{* *} 2, \beta=.645, t=$ $.837, p=.403$, nor Civic Engagement Exposure $* * 3, \beta=-.505, t=-1.012, p=.313$, was a significant individual predictor of future Behavioral Intentions. Beta weights can be found in Table 10.

Table 10

Cubic - Beta Weights for Behavioral Intention on Engagement Exposure

\begin{tabular}{lcccc}
\hline \multicolumn{1}{c}{ Predictor Variables } & $B$ & $S E B$ & $\beta$ \\
\hline Civic Engagement Exposure & & .010 & .041 & .079 \\
Civic Engagement Exposure**2 & & .003 & .004 & .645 \\
Civic Engagement Exposure**3 & & .000 & .000 & -.505 \\
& $R^{2}$ & & .076 & \\
& $R^{2}$ adj & & .064 & \\
& $F$ & & 6.154
\end{tabular}

Note. An * indicates a unique significant predictor variable at $p<.05 .(n=251)$

Growth. Testing growth indicated that $6.3 \%$ of the variance in future Behavioral Intentions could be predicted by Civic Engagement Exposure, $R_{\text {adj }}^{2}=.059, F(1,227)=$ 15.243, $p<.001$. Missing cases were excluded pairwise. Thus, the significant results of the regression procedure indicated that future Behavioral Intentions were able to account for significant amount of variance in Civic Engagement Exposure. Analysis of regression 
coefficients indicated that Civic Engagement Exposure, $\beta=.251, t=3.904, p<.001$, was a significant predictor. Beta weights can be found in Table 11.

Table 11

Growth - Beta Weights for Behavioral Intention on Engagement Exposure

\begin{tabular}{|c|c|c|c|c|}
\hline Variable & & $B$ & $S E B$ & $\beta$ \\
\hline \multirow[t]{4}{*}{ *Civic Engagement Exposure } & & .010 & .003 & .251 \\
\hline & $R^{2}$ & & .063 & \\
\hline & $R_{a d j}^{2}$ & & .059 & \\
\hline & $F$ & & 15.243 & \\
\hline
\end{tabular}

Note. An $*$ indicates a unique significant predictor variable at $p<.05 .(n=251)$

Exponential. The exponential analysis indicated that $6.3 \%$ of the variance in future Behavioral Intentions could be predicted by Civic Engagement Exposure, $R_{\text {adj }}^{2}=$ $.059, F(1,227)=15.243, p<.01$. Missing cases were excluded pairwise. Thus, the significant results of the regression procedure indicated that future Behavioral Intentions were able to account for significant amount of variance in Civic Engagement Exposure. Analysis of regression coefficients indicated that Civic Engagement Exposure, $\beta=.251, t$ $=3.904, p<.001$, was a significant predictor. Beta weights can be found in Table 12 . 
Table 12

Exponential - Beta Weights for Behavioral Intention on Engagement Exposure

\begin{tabular}{|c|c|c|c|c|}
\hline Variable & & $B$ & $S E B$ & $\beta$ \\
\hline \multirow[t]{4}{*}{ *Civic Engagement Exposure } & & .010 & .003 & .251 \\
\hline & $R^{2}$ & & .063 & \\
\hline & $R_{a d j}^{2}$ & & .059 & \\
\hline & $F$ & & 15.243 & \\
\hline
\end{tabular}

Note. An * indicates a unique significant predictor variable at $p<.05 .(n=251)$

\section{Summary of Research Question Five}

Research question five examined the curvilinear relationship between civic or political engagement exposure and behavior intentions for future engagement. The statistical procedures provided results from linear, cubic, quadratic, growth, and exponential relations. Additionally, the results were used to map the curvilinear relationship. Figure 2 shows that an inverted U-shaped curvilinear relationship can best describe the relationship between exposure and future engagement. 


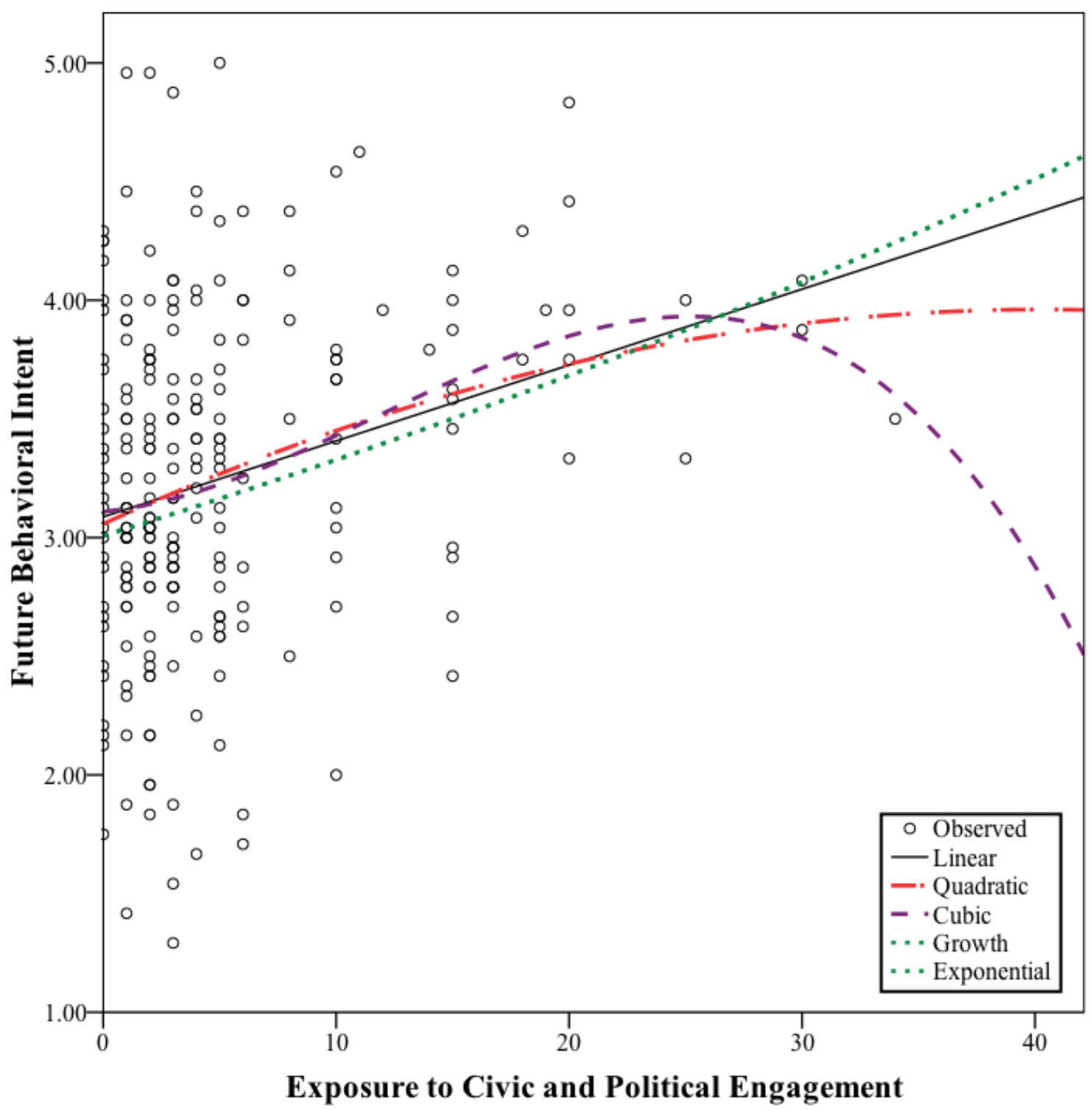

Figure 2. The Curvilinear Relationship between Classroom Exposure and Future Behavioral Intentions 


\section{Conclusion}

This chapter provided the results of research questions one through five. The majority of results indicated positive relationships between the variables. Additionally, the statistical tests were able to predict the significance between the variables. The next chapter will present an interpretation for the results, as well as the limitation and implications of this study. 


\section{CHAPTER IV}

\section{DISCUSSION}

The current study examined how the teaching of civic and political engagement information affects students' behavioral outcomes. Ajzen's $(1985,1991)$ theory of planned behavior (TPB) was used as a framework to help structure this study in order to

obtain results that synthesize previous literature terms and outcomes. Finley (2011) argues that "whatever approach is taken with regard to the assessment of civic engagement and psychosocial well-being, the goal should be to tell a coherent story about the ways in which these experiences shape students' lives and learning” (p. 56). Using a quantitative approach, this study was able to investigate the impact of teaching methods, explore the relationships amongst behavioral outcomes, and examine the curvilinear relationship of engagement.

This chapter will present an in-depth summary of the finding from this study. Then, this chapter will discuss the positive and negative implications derived from these tests.

\section{Summary of Findings}

\section{Teaching Styles and Future Engagement}

The first research question, a through c, investigated how the type of classroom communication (i.e., one-way teaching or two-way teaching) contributed to predicting 
civic and political engagement. The first part of the question sought to explain which type of teaching predict attitude towards future civic and political engagement. Results revealed that one-way teaching impacts attitudes toward civic and political engagement, though predicting only $1.8 \%$ of the variance in attitudes, while two-way teaching showed no significant signs of impacting this particular outcome. Unlike many studies that spotlight the importance of an active classroom experience (Colby et al., 2007), the results from this current study indicate that only passive teaching (e.g., assigned readings or lectures) enhances the civic and political engagement attitudes within students; furthermore, while this impact is significant, it does not seem to be strong.

The second and third parts of research question one sought to explore the types of teaching that better predict self-efficacy towards civic and political engagement and behavioral intention towards future civic and political engagement. In both cases, results indicated that neither one-way teaching nor two-way teaching has an impact on the outcome variables. These results support Knappet al.'s (2010) study that self-efficacy toward engagement did not increase due to teaching. However, this study contradicts other studies that show a positive impact between teaching and outcomes (Beaumont et al., 2006). For instance, Hunt et al. (2009) show that by incorporating civic and political initiatives, like the PEP program, teachers can increase self-efficacy and motivations within students.

Although, research question one results suggested that the majority of classroom teachings do not have a significant impact on behavioral outcomes, it was unclear why the results contradicted past studies. An additional test was conducted to see if students' behaviors (i.e., attitudes, self-efficacy, and future behavioral intentions) changed from 
their freshmen year to their senior year of college. The findings showed significant changes in attitude toward civic and political engagement, throughout their college career. However, there were no significant differences regarding self-efficacy and future behavioral intentions. This additional information, along with the three original findings (i.e., part one, two, and three), provided a more in-depth understanding regarding research question one results; specifically, students' attitudes toward civic and political engagement become more positive as they attend college, but this same change does not hold true for their efficacy and intention.

Additionally, it is not fully clear why one-way teaching (e.g., assigned readings) would be a better forecaster for attitudes toward civic and political engagement than interactive teaching approaches. The possible rationale for these results may be due to the amount students are interacting with passive teaching styles compared to the amount of times they are in involved in active learning. The stronger result might simply be due to more exposure to passive methods, thus creating a skewed result. However, this justification does not explain the lack of impact of one-way methods regarding the second and third portions of research question one. Further research is needed to better understand why one-way teaching is a better predictor for attitudes than two-way teaching.

College is often seen as a transitional period that aids in creating better intellectual and civically-mind citizens (Hunt, 2010; Jacoby, 2009). While past research suggests that the college career is the prime moment to impact students' civic and political perception (Colby et al., 2007), the current study reveals that teaching does not play as significant of role in changing behavior. The findings go on to indicate that 
students' attitudes, self-efficacy, and future behavior intentions are already strongly in place by their freshmen year, as indicated by the moderate to high means on these variables. These attitudes are either unshakable throughout the students' college career, or it is possible that the information they are receiving in the classroom has little to no effect on their current and future behavior. If college students' behavioral outcomes are so unshakable, future research should seek to study the perception of high school students regarding civic and political engagement, to see if there is a change during that time frame.

The last possible explanation for these results is that other collegiate activities have more of an impact on student outcomes. Throughout their years on campus, college and university students typically have a variety of opportunities to engage civically and politically. From philanthropic endeavors sponsored by fraternal organizations to political social groups to debate or forensics unions, most universities provide other options for students to build their attitudes, self-efficacy, and future behavioral intentions toward civic and political engagement. These extracurricular activities could have an effect on the communication occurring in the classroom.

One of the main theories involved in this current study is student involvement theory (Astin, 1984; Kuh 2001, 2003), which argues that current and future outcomes can be predict by the relationship between institutional settings and student behaviors. This study centered on active learning and passive learning as an impact towards students' civic and political engagement outcomes. Results show that neither form had a significant impact on the specific behavioral outcomes. More research is needed to better understand how theses aspects of the classroom experience did not have an impact on students. 


\section{Attitudes, Norms, Self-Efficacy, and Future Engagement}

Research question two pertained to how attitudes, norms, and self-efficacy might predict future civic engagement. The results indicate that the three variables (i.e., attitudes, norms, and self-efficacy) can predict behavioral intention toward future civic engagement. Furthermore, findings showed that attitudes are the strongest predictor of future engagement, followed by norms, and then self-efficacy. Consistent with other studies the results support the model of the TPB (Bruckner, 2011). The TPB model implies that attitudes, subjective norms, and perceived behavioral control (e.g., selfefficacy) work together to impact behavioral intentions toward a particular subject. In this study, the TPB model successfully works to predict future civic and political engagement intentions.

The findings suggest that focusing on these three variables, especially attitudes, will likely increase students' intent for future civic and political engagement; however, based on RQ one results, creating civic and political engagement initiatives for the classroom might not be the answer to help increase future behavioral intentions within students. Departments and organizations might need to look outside the classroom to achieve outcomes that lead to future intentions.

\section{Classroom Exposure and Self-Efficacy}

The third research question addressed whether the amount of classroom exposure contributes to the prediction of self-efficacy for civic and political engagement. The findings revealed strong evidence that classroom exposure can predict self-efficacy for civic and political engagement. This result supports previous literature that exposure can enhance an individual's confidence to complete a task (Bandura, 1977). In this case, the 
more civic engagement concepts students are exposed to in the classroom, the stronger they will believe they can engage in civic and political activities. While Schunk (1991) suggests that self-efficacy is not always the strongest predictor of intentions, positive self-efficacy can increase the probability that a person will perform the action. Thus, students may believe they can engage in more civic and political activities because of their exposure.

Additionally, the following research questions have shown how the theory of planned behavior was an important facet of this this study. Although the researcher did not implement the variables through the standard TPB measurement process, the variables still exhibited results similar to past theoretical research. Specifically, research question three demonstrates that social persuasion can alter self-efficacy behavior (Bandura, 1977). The current study also took a comprehensive look at civic and political engagement. Despite its broadness, the TPB was still able to operate each variable effectively. Therefore, the present shows that TPB has great elasticity when it comes to researching; whereas, the theory frequently has been used for persuasion studies, it also has relevance for the teaching of civic engagement.

\section{Classroom Exposure and Behavioral Intent}

Research question four inquired about how the amount of classroom exposure to civic and political engagement concepts might contribute to predicting behavioral intent toward future civic and political engagement. Strong results showed that behavioral intentions toward future civic and political engagement could be predicted by classroom exposure. 
Although the results of RQ4 support a linear relationship between classroom exposure and behavioral intent, it is possible that overexposure to civic engagement pedagogy, especially in an academic environment where such instruction is becoming a trend, might have a fatigue effect. Therefore, the fifth research question asked about a possible curvilinear relationship between classroom exposure and behavioral intent. The results presented that an inverted-U shaped curvilinear relationship can best describe the relationship between exposure and future engagement. The average student exposed to a few civic and political engagement classes showed intent to participate in engagement activities only occasionally. As students attended more classes with engagement exposure, their likelihood to participate increased. Once they reached approximately 25 classroom exposures, their intent peaked, from occasionally too often. After 25 classroom exposures, students' intent gradually decreased.

Results show that there is a possible fatigue effect due to being overexposed to civic and political engagement curriculum. However, most students do not enroll in 25 classes during their college career. Additionally, the findings maintain a pattern seen throughout this study; it is difficult to change a behavioral outcome. In this case, the amount of classes to transition from one emotional response to another response regarding future engagement intentions is significant. Our understanding of the curvilinear relationship also has room for improvement concerning responses to future behavioral intentions.

This concept might not actually be as relevant in the civic and political engagement arena, but it is important that scholars question and study the adverse effects of engagement initiatives. More studies are necessary to determine if the mere-exposure 
of civic and political engagement maintains positive reception in the classroom.

\section{Strengths and Limitations}

Like all studies, there are strengths and limitations to this study. The following sections will discuss the strengths, limitations, future directions, and practical implications of this study.

\section{Limitations and Directions for Future Research}

Limitations. The first limitation of this study involved the survey design. There were a couple of errors regarding how the survey was presented to participants. First, participants might have been confused with the scale options in self-efficacy portion of the survey. The question asked, "Working with people, how hard or easy would it be for you to accomplish these goals?" The researcher employed responses ranging from 1 (extremely not effective) to 5 (extremely effective). Alternatively, the responses should have been ranging from 1 (impossible to get done) to 5 (easy to get done). While the overall responses to this measure correlated with the likely responses, it is important that appropriate responses be provided to improve accuracy.

Additionally, the College of Business was missing from the academic colleges section of the demographics measure. Eventually, the option was added on to the survey. There is a possibility that some participants marked a different category in response to the missing option. Thus, the results involving the academic colleges could be skewed just a bit; however, as no predictions or analyses were made involving college of student study, this limitation is minor.

Another limitation of this study is the inability to determine causality. Quantitative studies, specifically involving Likert-type questionnaires, have an inherent 
disadvantage of not being able to provide information regarding the cause of certain actions. While this study provides many reasonable hypotheses as to why these results are occurring, the researcher cannot overtly describe the causes that affect a student's behavior toward engagement.

Next, there could be a better way to test the curvilinear of future intentions toward civic and political engagement. This study used a curve estimation regression procedure to tabulate the results of research question five. Analyzing the "mere-exposure" and "fatigue" effect regarding classroom exposure and behavioral intent is not a common focus of study. Thus, alternative approaches should be researched and executed to determine the best method for such analysis. In addition, the fact that this is a one-time data collection study potentially limited the validity of the findings. To receive a more accurate analysis of civic engagement fatigue or behavior outcomes from freshman to senior of college, participants need to take the survey multiple times over a period of time. A longitudinal study design would be necessary to achieve this goal.

Recommendations for future research. While aspects of this study had certain limitations, there is always room for improvement in future studies. Based on the evidence obtained in this study, suggestions for future research will be presented in the following paragraphs.

The first recommendation for future research is to expand the random sampling size. This study only focused on sampling one Midwestern university, which limited the generalizability. Thus, extending to more colleges and universities will provide more accurate depiction of civic and political engagement outcomes.

Next, the researcher suggests that a longitudinal study be implemented to further 
study how the type of classroom communication (e.g., one-way teaching and two-way teaching) predicts civic engagement outcomes. In the current study, the results contradicted past literature. The post hoc analyses provided a better explanation how each outcome (i.e., attitude, self-efficacy, intentions) did not significantly change from freshman to sophomore year. Multiple tests throughout students' college career would better determine the impact of active and passive learning strategies.

Hoekema and Ehrlich (2000) argue that engagement is a combination of knowledge, skills, values, and motivation. This study primarily focuses on the motivation and behavioral outcomes of learning civic and political engagement in a classroom setting. Future research should analyze the civic and political engagement knowledge and skills students are gaining from college courses. This study shows that students are being exposed to civic and political engagement material in a lot of classes. While their motivations seem to stay predominately the same throughout their college career, their knowledge regarding engagement might have more dramatic change. Fourth, the researcher recommends exploring impacts of collegiate extracurricular activities (e.g., fraternities, sororities, debate, forensic speaking, and other campus organizations) towards civic and political engagement behavioral outcomes. The current study only provides evidence regarding the impacts of interactions in the classroom. Stewart (2010) provides research that an activity like debate can provide benefits that expand students' behaviors toward engagement. There is a wide-range of civic and political engagement interactions that need to be studied further. The conversations, teachings, and engagement that occur outside of the classroom may have just as much an effect on behavior as to what is happening inside the classroom. 
This study presented quantitative results that explore how what happens in the classroom affects civic and political behavior outcomes. Future research might take a more qualitative approach to finding results. By using a combination of self-report, observation, focus groups, and interviews, scholars might better explain the inquires proposed in this study. This research recommends that future scholars implement selfreports to help better understand civic and political engagement. This method will allow students to describe their own emotions, motives, and thought processes when engaging in civic and political activities (Lindlof \& Taylor, 2011). It is important that quantitative and qualitative research maintain a parallel relationship as scholars explore future topics. Qualitative data would provide a dimension to this research that quantitative research could not effectively accomplish. More specifically, qualitative data could provide a deeper meaning of civic and political engagement through personal accounts and observations.

The final recommendation is to continue the study of civic and political disengagement, more specifically the possible fatigue effect within engagement. A longitudinal study of exposure is necessary to acquire a better understanding of this phenomenon. Furthermore, determining the curvilinear relationship between exposure and behavioral outcomes, specifically intentions, requires the investigation of more possible factors than just the possibility of burnout. Although behavioral intent in the current study peaked at a certain point before appearing to decrease, multiple tests of over a period of time could expose factors that contribute to civic engagement outcomes peaking and decreasing. Of course, readers may believe that the present researcher is claiming that there is negative side to civic engagement instruction; however, it is not the 
intention of the researcher to make those types of claims toward civic engagement. Civic and political engagement is normally presented as a constructive discipline. In other words, civic engagement progresses society for the better. However, it is important that scholars and researchers attempt to analyze the "dark side" of every discipline, including civic and political engagement. There is a significant possibility that further analyzing the disengagement of citizenship will provide evidence to help scholars and organizations better equip communities.

\section{Practical Implications}

As scholars, we research aspects of communication, as well as other fields, in order to add to the "body of knowledge." While this study contributes more knowledge to civic engagement, political engagement, communication, theory of planned behavior, and many other areas of research, it also can contribute some practical implications for the betterment of society.

Initially, civic and political disengagement among the youth of this country is an issue that should concern all of those in higher education (Hunt, 2010). Colleges and universities play a central role in building civic and political-minded citizens (Checkoway, 2001). However, this study suggests that classroom instruction has no effect on students' civic and political engagement outcomes. With certain forms of citizen participation decreasing (e.g., voting), now is the time to figure out ways to enhance college curriculum toward civic and political engagement.

Instructors have an obligation to help develop students into good citizens. In this study, it is apparent that students are being exposed to a lot of engagement material throughout their college career. However, instructors need to be mindful of their 
curriculum, making students feel like civic and political engagement is a requirement or obligation, rather than a positive habit to develop to be a good citizen in society. Additionally, high school instructors may have an even greater impact regarding fostering of civically and politically-minded individuals.

College departments, like departments of communication or business, should discuss ways to implement department-wide plans to foster civic and political engagement in the classroom. Most four-year students have chosen a major by the time they reach their junior year. This gives departments ample opportunities to impact student outcomes. Although incorporating civic and political engagement curriculum into all department course would help in the grand scheme of engagement awareness, faculty should work together to figure out ways to make civic engagement efforts in later courses build off of what happens in earlier courses.

In this current study, there was a small but not significant increase in future intentions due to classroom exposure. It is good to see that it is possible that more classes a student takes (up to a point) that have civic engagement components, the more likely he or she is going to engage in citizenship in the future. However, the findings regarding the relationship between teaching style and students' behavior suggest that outcomes did not change due to teaching. There is a possibility that outside forces have more impact than events happening in the classroom. Therefore, departments should to find ways to make classes feel like building blocks as part of a larger university effort in regards to civic and political engagement learning.

Currently, students might be learning civic and political engagement concepts in a majority of their classes. While that appears to be a benefit to the promotion of civic and 
political engagement, there is also a possibility that they are learning the same information in all of the classes. Just like the need to add to the "body of knowledge" in academia, students need to feel that they are learning more in each class they experience. Initiatives, like the American Democracy Project, Political Engagement Project, and Association of American Colleges and Universities, have set the foundation for better engagement policies on campuses. Now, it is time to make sure that these initiatives take root in courses across the country.

\section{Conclusion}

The goal of this study was to analyze how classroom interaction affected students' civic and political engagement outcomes. Results show that neither active nor passive teaching in the classroom provides much impact on students' behavioral outcomes, and, in most cases, any impacts are statistically insignificant. At the same time, self-efficacy, subjective norm, and attitudes can predict future intentions toward civic and political engagement. These findings suggest that instructors and initiatives of civic and political engagement need to find new ways, possibly outside of the classroom, to bolster students' sense of civic responsibility. By continuing to strive for excellence in civic and political engagement curriculum, universities and colleges will be better prepared to help foster the citizens of tomorrow. 


\section{REFERENCES}

Ajzen, I. (1985). From intentions to actions: A theory of planned behavior. In J. Kuhl \& J. Beckmann (Eds.), Action control: From cognition to behavior (pp. 11-31). Berlin: Springer-Verlag.

Ajzen, I. (1987). Attitudes, traits, and actions: Dispositional prediction of behavior in personality and social psychology. Advances in Experimental Social Psychology, 20(1), 1-63. doi: 10.1016/s0065-2601(08)60411-6

Ajzen, I. (1988). Attitudes, personality, and behavior. Chicago, IL: Dorsey Press.

Ajzen, I (1989). Attitude structure and behavior. In A. R. Pratkanis, S. J. Breckler, \& A. G. Greenwald (Eds.), Attitude structure and function (pp. 241-274). Hillsdale, NJ: Lawrence Erlbaum.

Ajzen, I. (1991). The theory of planned behavior. Organizational Behavior and Human Decision Processes, 50(2), 179-211. doi: 10.1016/0749-5978(91)90020-t

Ajzen, I., \& Driver, B. L. (1991). Prediction of leisure participation from behavioral, normative, and control beliefs: An application of the theory of planned behavior. Leisure Sciences, 13, 185-204. doi: 10.1080/01490409109513137

Ajzen, I., \& Fishbein, M. (1977). Attitude-behavior relations: A theoretical analysis and review of empirical research. Psychological bulletin, 84(5), 888-918. doi: 10.1037/0033-2909.84.5.888

Ajzen, I. (2005). Attitudes, personality, and behavior. Chicago, IL: Dorsey Press.

Ajzen, I. (1989). Attitude structure and behavior. In A. R. Pratkanis, S. J. Beckler, \& A. G. Greenwald (Eds.), Attitude structure and function (pp. 241-274). Hillsdale, NJ: Lawrence Erlbaum.

Anaya, G. (1996). College experiences and student learning: The influence of active learning, college environments and cocurricular activities. Journal of College Student Development, 37(6), 611-22. Retrieved from http://muse.jhu.edu/journals/journal_of_college_student_development/

Astin, A. W. (1984). Student involvement: A developmental theory for higher education. Journal of College Student Personnel, 25(4), 297-308. 
Astin, A. W., Vogelgesang, L. J., Ikeda, E. K., \& Yee, J. A. (2000). How service learning affects students. Los Angeles, CA: Higher Education Research Institute, University of California.

Balsano, A. B. (2005). Youth civic engagement in the United States: Understanding and addressing the impact of social impediments on positive youth and community development. Applied Developmental Science, 9, 188-201. doi: $10.1207 / \mathrm{s} 1532480 x a d s 0904$ 2

Bandura, A. (1977). Self-efficacy: Toward a unifying theory of behavioral change. Psychological Review, 84, 191-215. doi: 10.1037/0033-295x.84.2.191

Bandura, A. (1986). Social foundations of thought and action: A social cognitive theory. Englewood Cliffs, NJ: Prentice-Hall.

Bandura, A. (1989). Human agency in social cognitive theory. American Psychologist, 44, 1175-1184. doi: 10.1037/0003-066x.44.9.1175

Bandura, A. (1997). Self-efficacy: the exercise of control. New York, NY: W.H. Freeman.

Battistoni, R. M. (1997). Service learning and democratic citizenship. Theory into Practice, 36(3), 150-156. doi: 10.1080/00405849709543761

Battistoni, R. M. (2002). Civic engagement across the curriculum: A resource book for service-learning faculty in all disciplines. Providence, RI: Campus Compact.

Bandura, A., \& Wood, R. (1989). Effect of perceived controllability and performance standards on self-regulation of complex decision making. Journal of Personality and Social Psychology, 56, 805-814. doi: 10.1037/0022-3514.56.5.805

Bass, F. M., Bruce, N., Majumdar, S., \& Murthi, B. P. S. (2007). Wearout effects of different advertising themes: A dynamic Bayesian model of the advertising-sales relationship. Marketing Science, 26(2), 179-195. doi: 10.1287/mksc.1060.0208

Beaumont, E., Colby, A., Ehrlich, T., \& Torney-Purta, J. (2006). Promoting political competence and engagement in college students: An empirical study. Journal of Political Science Education, 2, 249-270. doi: 10.1080/15512160600840467

Benek-Rivera, J., \& Mathews, V. E. (2004). Active learning with jeopardy: Students ask the questions_- Journal of Management Education, 28(1), 104-118. doi: $10.1177 / 1052562903252637$

Berger, J. B., \& Milem, J. F. (1999). The role of student involvement and perceptions of integration in a causal model of student persistence. Research in Higher Education, 40(6), 641-664. doi: 10.1023/A:1018708813711 
Berlyne, D. E. (1970). Novelty, complexity, and hedonic value. Perception and Psychophysics, 8(5), 279-286. doi: 10.3758/bf03212593

Bohman, J. (Ed.). (1997). Deliberative democracy: Essays on reason and politics. Cambridge, MA: MIT Press.

Bomia, L., Beluzo, L., Demeester, D., Elander, K., Johnson, M., \& Sheldon, B. (1997). The Impact of Teaching Strategies on Intrinsic Motivation. Champaign, IL: ERIC Clearinghouse on Elementary and Early Childhood Education.

Bonwell, C. C., \& Eison, J. A. (1991). Active Learning: Creating Excitement in the Classroom. Washington, DC: ERIC Clearinghouse on Higher Education, The George Washington University.

Boyd, K. D., \& Brackmann, S. (2012). Promoting civic engagement to educate institutionally for personal and social responsibility. New Directions for Student Services, 2012(139), 39-50. doi: 10.1002/ss.20021

Boyer, E. L. (1996). The scholarship of engagement. Bulletin of the American Academy of Arts and Sciences, 49(7), 18-33. doi: 10.2307/3824459

Bringle, R. G., \& Hatcher, J. A. (1996). Implementing service learning in higher education. The Journal of Higher Education, 67(2) 221-239.

Bruckner C. M. (2011). Communication and civic and political engagement: An application of the theory of planned behavior (master's thesis). Illinois State University, Illinois.

Brulle, R. J. (2010). From environmental campaigns to advancing the public dialog: Environmental communication for civic engagement. Environmental Communication: A Journal of Nature and Culture, 4(1), 82-98. doi: $10.1080 / 17524030903522397$

Butin, D. W. (2006). The limits of service-learning in higher education. The Review of Higher Education, 29(4), 473-498. doi: 10.1353/rhe.2006.0025

Calder, B. J., \& Sternthal, B. (1980). Television commercial wearout: An information processing view. Journal of Marketing Research (JMR), 17(2), 173-186. doi: $10.2307 / 3150928$

Cantor, N. (2004). Civic engagement. The university as a public good. Liberal Education, 90(2), 18-25.

Cha, J. (2013). Predictors of television and online video platform use: A coexistence model of old and new video platforms. Telematics and Informatics, 30, 296-310. doi: $10.1016 / j$.tele.2013.01.001 
Chapman, E. (2003). Assessing Student Engagement Rates. ERIC Digest. ERIC Clearinghouse on Assessment and Evaluation College Park MD, 1-7.

Checkoway, B. (2001). Renewing the civic mission of the American research university. The Journal of Higher Education, 72(2), 125-147. doi: 10.2307/2649319

Chickering, A. W., \& Gamson, Z. F. (1987). Seven principles for good practice in undergraduate education. AAHE bulletin, 3, 7. doi :10.1016/0307-4412(89)900940

Chickering, A. W., \& Reisser, L. (1993). Education and Identity. The Jossey-Bass Higher and Adult Education Series. San Francisco, CA: Jossey-Bass Inc.

Coalition for Civic Engagement and Leadership. (2005). Working definition of civic engagement. Retrieved from http://www.terpimpact.umd.edu/content2.asp?cid $=7 \&$ sid $=41$

Colby, A., Beamont, E., Ehrlich, T., \& Corngold, J. (2007). Educating for democracy: Preparing undergraduates for responsible political engagement. San Francisco, CA: Jossey-Bass.

Corporation for National and Community Service. (2009). Volunteering in America. Retrieved from http://www.fs.usda.gov/Internet/FSE_DOCUMENTS/stelprdb5108473.pdf

Danaher, P. J. (1996). Wearout effects in target marketing. Marketing Letters, 7(3), 275287. doi: $10.1007 / \mathrm{bf} 00435743$

DeVellis, R. F. (2003). Scale development: Theory and applications (2nd ed.): Vol 26. Applied social research methods series. Thousand Oaks, CA: Sage.

Dewey, J. (1981). My pedagogic creed. In J. J. McDemott (Ed.), The philosophy of John Dewey (pp. 442-454). Chicago, IL: The University of Chicago Press. (Original work published 1897)

Dorestani, A. (2005). Is interactive/active learning superior to traditional lecturing in economics courses? Humanomics, 2l(1), 1-20. doi: 10.1108/eb018897

Downs, D. A. (2012). Civic education versus civic engagement. Academic Questions, 15. doi: 10.1007/s12129-012-9302-y

Eagly, A. E., \& Chaiken, S. (1995). Attitude strength, attitude structure and resistance to change. In R. Petty \& J. A. Krosnick (Eds.), Attitude strength: Antecedents and consequences (pp. 413-432). Mahwah, NJ: Lawrence Erlbaum. 
Eccles, J. S., \& Barber, B. L. (1999). Student council, volunteering, basketball, or marching band: What kind of extracurricular involvement matters? Journal of Adolescent Research, 14(1), 10-43. doi: 10.1177/0743558499141003

Ehrlich, T. (Ed.). (2000). Civic responsibility and higher education. Westport, CT: Oryx Press.

Ebert-May, D., Brewer, C., \& Allred, S. (1997). Innovation in large lectures: Teaching for active learning. Bioscience, 601-607. doi: 10.2307/1313166

Evans, S. D., \& Prilleltensky, I. (2007). Youth and democracy: Participation for personal, relational, and collective well-being. Journal of Community Psychology, 35, 681692. doi: $10.1002 /$ jcop. 20172

Eyler, J., Giles Jr, D. E., Stenson, C. M., \& Gray, C. J. (2001). At a glance: What we know about the effects of service-learning on college students, faculty, institutions and communities, 1993-2000. Nashville, TN: Vanderbilt University.

Fang, X., Singh, S., \& Ahluwalia, R. (2007). An examination of different explanations for the mere exposure effect. Journal of Consumer Research, 34(1), 97-103. doi: $10.1086 / 513050$

Fazio, R. H. (1989). On the power and functionality of attitude: The role of attitude accessibility. In A. R. Pratkanis, S. J. Breckler, \& A. G. Greenwald (Eds.). Attitude structure and function. (pp. 153-179). Hillsdale, NJ: Lawrence Erlbaum.

Fazio, R. H., \& Zanna, M. P. (1981). Direct experience and attitude-behavior consistency. In L. Berkowtiz (Ed.), Advances in experimental social psychology: Vol. 14 (pp. 161-202). San Diego, CA: Academic Press.

Finley, A. (2011). Connecting the dots: A methodological approach for assessing students' civic engagement and psychosocial well-being. Liberal Education, $97(2), 52-56$.

Flanagan, C., \& Levine, P. (2010). Civic engagement and the transition to adulthood. The Future of Children, 20(1), 159-179. doi: 10.1353/foc.0.0043

Furco, A. (2002). Is service-learning really better than community service? In A. Furco \& S. H. Billig (Eds.) Service-learning: The essence of pedagogy (p. 25). Greenwich, CT: Information Age Publishing.

Galston, W. A. (2001). Political knowledge, political engagement, and civic education. Annual Review of Political Science 4, 217-34. doi:

10.1146/annurev.polisci.4.1.217 
Godin, G., \& Kok, G. (1996). The theory of planned behavior: A review of its applications to health-related behaviors. American Journal of Health Promotion, 11(2), 87-98. doi: 10.4278/0890-1171-11.2.87

Goodman, R., \& Refsing, K. (Eds.). (2002). Ideology and practice in modern Japan. London, UK: Routledge.

Grass, R. C., \& Wallace, W. H. (1969). Satiation effects of TV commercials. Journal of Advertising Research, 9(3), 3-8.

Greyser, S. A. (1973). Irritation in advertising. New York, NY: Advertising Research Foundation.

Goss, K. A. (2000). Better together: Report of the Saguaro Seminar: Civic engagement in America. Cambridge, MA: Cambridge, MA: John F. Kennedy School of Government, Harvard University.

Harkavy, I. (2006). The role of universities in advancing citizenship and social justice in the 21st century. Education, Citizenship and Social Justice, 1(1), 5-37. doi: $10.1177 / 1746197906060711$

Harmon-Jones, E., \& Allen, J. J. (2001). The role of affect in the mere exposure effect: Evidence from psychophysiological and individual differences approaches. Personality and Social Psychology Bulletin, 27(7), 889-898. doi: 10.1177/0146167201277011

Hart, R. A. (1992). Children's participation: From tokenism to citizenship. Florence, Italy: UNICEF International Child Development Center.

Hillygus, D. S. (2005). The missing link: Exploring the relationship between higher education and political engagement. Political Behavior, 27(1), 25-47. doi: $10.1007 / \mathrm{s} 11109-005-3075-8$

Hoekema, D. A., \& Ehrlich, T. (2000). Civic responsibility and higher education. Academe, 86(5), 79-80. doi: 10.2307/40251931

Hu, S., \& Kuh, G. D. (2003). Maximizing what students get out of college: Testing a learning productivity model. Journal of College Student Development, 44(2), 185203. doi: $10.1353 /$ csd.2003.0016

Hunt, S. K. (2010). Curricular activities for political engagement. In J.Goldfinger \& J. W. Presley (Eds.), Educating students for political engagement: A Guide to implementation and assessment for colleges and universities (pp. 46-62). Washington, DC: American Association of State Colleges and Universities. 
Hunt, S. K., Simonds, C. J., \& Simonds, B. K. (2009). Uniquely qualified, distinctively competent: Delivering 21st century skills in the basic course. Basic Communication Course Annual, 21, 1-24. Retrieved from http://www.americanpresspublishers.com/BCCA.html

Jacoby, B. (2009). Civic engagement in higher education. San Francisco, CA: JosseyBass.

Kahne, J., \& Sporte, S. (2008). Developing citizens: The impact of civic learning opportunities on students' commitment to civic participation. American Educational Research Journal, 45, 738-766. doi: 10.3102/0002831208316951

Keiser, M. (2000). Young adults and civic participation. National Civic Review, 89(1), 33-38. doi: 10.1002/ncr.89106

Kelly-Woessner, A., \& Woessner, M.C. (2006). My professor is a partisan hack: How perceptions of a professor's political views affect student course evaluations. $P S$ : Political Science and Politics, 39, 495-501. doi: 10.1017/S104909650606080X

Knapp, T., Fisher, B., \& Levesque-Bristol, C. (2010). Service-learning's impact on college Students' commitment to future civic engagement, self-efficacy, and social empowerment. Journal of Community Practice, 18(2-3), 233-251. doi: $10.1080 / 10705422.2010 .490152$

Kochman, T. (1985). Black American speech event and a language program for the classroom. In C. B. Cazden, V. P. John \& D. Hymes (Eds), Functions of language in the classroom (pp. 211-261). Prospect Heights, IL: Waveland.

Kuh, G. D. (2001). Assessing what really matters to student learning inside the national survey of student engagement. Change: The Magazine of Higher Learning, 33(3), 10-17. doi: 10.1080/00091380109601795

Kuh, G. D. (2003). What we're learning about student engagement from NSSE:

Benchmarks for effective educational practices. Change: The Magazine of Higher Learning, 35(2), 24-32. doi: 10.1080/00091380309604090

Lehnert, K., Till, B. D., \& Carlson, B. D. (2013). Advertising creativity and repetition. International Journal of Advertising, 32(2), 211-231. doi: 10.2501/IJA-32-2-211231.

Locklin, R. B. (2012). Civic engagement in higher education: Concepts and practices By Barbara Jacoby and Associates. Teaching Theology \& Religion, 15, 196-197. doi: 10.1111/j.1467-9647.2012.00793.x

Lamm, E. J. (2009). Civic engagement among students in a communication course: A case study (doctoral dissertation). University of Maryland, Maryland. 
Lawry, S., Laurison, D., \& Van Antwerpen, J. (2006). Liberal Education and Civic Engagement: Ford Foundation's Knowledge, Creativity and Freedom Program. Retrieved from http://www.academia.edu/4245819/LIBERAL_EDUCATION_AND_CIVIC_EN GAGEMENT_A_Project_of_The_Ford_Foundations_Knowledge_Creativity_and _Freedom_Program

Levine, P. (2007). The future of democracy: Developing the next generation of American citizens. Hanover, NH: Tufts University Press.

Lindlof, T. R., \& Taylor, B. C. (2011). Qualitative communication research methods. London: Sage.

Liska, A. E. (1984). A critical examination of the causal structure of the Fishbein/Ajzen attitude-behavior model. Social Psychology Quarterly, 47(1), 61-74. doi: $10.2307 / 3033889$

London, S. (2001). Higher education and public life: Restoring the bond. Dayton, OH: Kettering Foundation.

Macedo, S. (2005). Democracy at risk how political choices undermine citizen participation and what we can do about it. Washington, DC: Brookings Institution Press.

MacFarlane, K., \& Woolfson, L. M. (2013). Teacher attitudes and behavior toward the inclusion of children with social, emotional and behavioral difficulties in mainstream schools: An application of the theory of planned behavior. Teaching and Teacher Education, 29, 46-52. doi: 10.1016/j.tate.2012.08.006

Maddux, J. E. (1995). Self-efficacy, adaption, and adjustment: Theory, research, and application. New York, NY: Plenum Press.

Miner, F. C., Jr., Das, H., \& Gale, J. (1984). An investigation of the relative effectiveness of three diverse teaching methodologies. Organizational Behavior Teaching Review, 9, 49-59. doi: 10.1177/10525629840090020

Minkoff, D. C. (1997). Producing social capital: National social movements and civil society. American Behavioral Scientist, 40, 606-619. doi:

10.1177/0002764297040005007

Mondak, J. J., \& Gearing, A. F. (1998). Civic Engagement in a Post Communist State. Political Psychology, 19(3), 615-637. doi:10.1111/0162-895x.00121

Murphy, T. A. (2004). Deliberative civic education and civil society: a consideration of ideals and actualities in democracy and communication education. Communication Education, 53(1). 74-91. doi: 10.1080/0363452032000135788 
Myers-Lipton, S. (1998). Effect of a comprehensive service-learning program on college students' level of civic responsibility. Teaching Sociology, 26, 243-258. doi:

$10.2307 / 1318766$

Naik, P. A., Mantrala, M. K., \& Sawyer, A. G. (1998). Planning media schedules in the presence of dynamic advertising quality. Marketing Science, 17(3), 214-235. doi: $10.1287 / \mathrm{mksc} .17 .3 .214$

Nocella, G., Boecker, A., Hubbard, L., \& Scarpa, R. (2012). Eliciting Consumer Preferences for Certified Animal Friendly Foods: Can Elements of the Theory of Planned Behavior Improve Choice Experiment Analysis? Psychology \& Marketing, 29(11), 850-868. doi: 10.1002/mar.20569

Putnam, R. (1993). The prosperous community: Social capital and public life. The American Prospect, 4(13), 35-42. Retrieved from: http://www.prospect. org/print/vol/13

Putnam, R. D. (2000). Bowling alone: The collapse and revival of American community. New York, NY: Simon and Schuster.

Reinke, S. J. (2003). Making a difference: Does service-learning promote civic engagement in MPA students? Journal of Public Affairs Education, 9(2) 129-138.

Rosenstone, S. J., \& Hansen, J. M. (1993). Mobilization, participation, and democracy in America. New York, NY: Macmillan

Saltmarsh, J. (2005). The civic promise of service learning. Liberal Education, 91(2), 5055 .

Sarason, Y., \& Banbury, C. (2004). Active learning facilitated by using a game-show format or who doesn't want to be a millionaire? Journal of Management Education, 28(4), 509-518. doi: 10.1177/1052562903260808

Sarver, T. V. (1983). Ajzen and Fishbein's “Theory of Reasoned Action”: A critical assessment. Journal for the Theory of Social Behaviour, 13, 155-164. doi: 10.1111/j.1468-5914.1983.tb00469.x

Schunk, D. H. (1991). Self-efficacy and academic motivation. Educational Psychologist, 26, 207-231. doi: 10.1080/00461520.1991.9653133

Sheppard, B. H., Hartwick, J., \& Warshaw, P. R. (1988). The theory of reasoned action: A meta-analysis of past research with recommendations for modifications and future research. Journal of consumer Research, 15, 325-343. doi: 10.1086/209170

Simon, H. (1982). ADPULS: An advertising model with wearout and pulsation. Journal of Marketing Research (JMR), 19(3), 352-363. doi: 10.2307/3151569 
Skinner, E. A., \& Belmont, M. J. (1993). Motivation in the classroom: Reciprocal effects of teacher behavior and student engagement across the school year. Journal of Educational Psychology, 85(4), 571. doi: 10.1037/0022-0663.85.4.571

Skocpol, T., \& Fiorina, M. P. (1999). Making sense of the civic engagement debate. In T. Skocpol \& M. P. Fiorina (Eds.) Civic engagement in American democracy (pp. 123). Washington, DC: The Brookings Institution Press and the Russell Sage Foundation.

Songer-Nocks, E. (1976). Situational factors affecting the weighting of predictor components in the Fishbein model. Journal of Experimental Social Psychology, 12(1), 56-69. doi: 10.1016/0022-1031(76)90086-x

Spiezio, K. E., Baker, K. Q., \& Boland, K. (2006). General education and civic engagement: An empirical analysis of pedagogical possibilities. The Journal of General Education, 54, 273-292. doi: 10.1353/jge.2006.0012

Splitter, L. J. (1995). On the theme of "Teaching for Higher Order Skills." Retrived from: http://www.Shss.Montclair.edu/inquiry/summ95/splitter.html

Stewart, N. T. (2010). Debating the pedagogy of political engagement: Pursuing the application of competitive academic debate to achieve the political engagement project's goals (master's thesis). Illinois State University, Illinois.

Torney-Purta, J. (2002). The school's role in developing civic engagement: A study of adolescents in the twenty-eight countries. Applied Developmental Science, 6, 203-212. doi: 10.1207/S1532480XADS0604_7

van den Putte, B. (1991). 20 years of the theory of reasoned action of Fishbein and Ajzen: A meta-analysis. Unpublished manuscript, University of Amsterdam, the Netherlands.

Van Eynde, D. F., \& Spencer, R. W. (1988). Lecture versus experiential learning: Their different effects on long-term memory. Organizational Behavior Teaching Review, 12, 52-58. doi: 10.1177/105256298801200404

Wang, X. (2009). Integrating the theory of planned behavior and attitude functions: Implications for health campaign design. Health Communication, 24, 426-434. doi: $10.1080 / 10410230903023477$

Weilbacher, W. M. (1970). What happens to advertisements when they grow up. Public Opinion Quarterly, 34(2), 216-223. doi: 10.1086/267791

Weinstein, E. (2014). The personal is political on social media: Online civic expression patterns and pathways among civically engaged youth. International Journal of Communication, 8, 210-233. 
Wheeless, V. E., Witt, P. L., Maresh, M., Bryand, M. C., \& Schrodt, P. (2011). Instructor credibility as a mediator of instructor communication and students' intent to persist in college. Communication Education, 60, 314-229. doi: 10.1080/03634523.2011.555917

Whetten, D. A., \& Clark, S. C. (1996). An integrated model for teaching management skills. Journal of Management Education, 20(2), 152-181. doi: $10.1177 / 105256299602000202$

Wilkin, H. A., Katz, V. S., \& Ball-Rokeach, S. J. (2009). The role of family interaction in new immigrant Latinos' civic engagement. Journal of Communication, 59, 387406. doi: 10.1111/j.1460-2466.2009.01421.x

Wingfield, S. S., \& Black, G. S. (2005). Active versus passive course designs: The impact on student outcomes. Journal of Education for Business, 81(2), 119-123. doi: $10.3200 /$ joeb.81.2.119-128

Xiao, J. J., Tang, C., Serido, J., \& Shim, S. (2011). Antecedents and consequences of risky credit behavior among college students: Application and extension of the theory of planned behavior. Journal of Public Policy \& Marketing, 30, 239-245. doi: 10.1509/jppm.30.2.239

Xiao Wang, \& McClung, S. R. (2011). Toward a detailed understanding of illegal digital downloading intentions: An extended theory of planned behavior approach. New Media \& Society, 13, 663-677. doi: 10.1177/1461444810378225

Youniss, J. (2009). Why we need to learn more about youth civic engagement. Social Forces, 88, 971-975. doi: 10.1353/sof.0.0253

Zajonc, R. B. (1968). Attitudinal effects of mere exposure. Journal of Personality and Social, 9(2, Pt.2), 1-27. doi: 10.1037/h0025848

Zajonc, R. B. (2001). Mere exposure: A gateway to the subliminal. Current Directions in Psychological Science, 10(6), 224-228. doi: 10.1111/1467-8721.00154

Zlotkowski, E. (1999). Pedagogy and engagement. In R. G. Bringle, R. Games, \& E. A. Mallory (Eds.), Colleges and universities as citizens (pp. 96-120). Boston, MA: Allyn and Bacon. 
APPENDIX A

SURVEY INSTRUMENT 


\section{PRELIMINARY QUESTIONAIRE}

1. How many of your past classes incorporated community issues, politics, or volunteerism into

1. number of classes the course?

How often were each of these activities incorporated into your past college courses?

1 - Extremely Infrequent, 2 - Infrequent, 3 - Neutral, 4 - Frequent, 5 - Extremely Frequent

\begin{tabular}{|c|c|c|c|c|c|}
\hline $\begin{array}{l}\text { 2. Assigned readings about politics, community } \\
\text { issues, or volunteering }\end{array}$ & 1 & 2 & 3 & 4 & 5 \\
\hline 3. Discussions about politics & 1 & 2 & 3 & 4 & 5 \\
\hline $\begin{array}{l}\text { 4. Discussions about community issues or } \\
\text { volunteering }\end{array}$ & 1 & 2 & 3 & 4 & 5 \\
\hline $\begin{array}{l}\text { 5. Required participation with a political group or } \\
\text { office }\end{array}$ & 1 & 2 & 3 & 4 & 5 \\
\hline $\begin{array}{l}\text { 6. Required participation in a service-learning } \\
\text { project or volunteering }\end{array}$ & 1 & 2 & 3 & 4 & 5 \\
\hline $\begin{array}{l}\text { 7. Classroom lectures about community issues, } \\
\text { politics, or volunteering }\end{array}$ & 1 & 2 & 3 & 4 & 5 \\
\hline $\begin{array}{l}\text { 8. Attending outside lectures or talks related to } \\
\text { politics, community issues, or volunteering }\end{array}$ & 1 & 2 & 3 & 4 & 5 \\
\hline $\begin{array}{l}\text { 9. Research papers or projects related to politics, } \\
\text { community issues, or volunteering }\end{array}$ & 1 & 2 & 3 & 4 & 5 \\
\hline
\end{tabular}




\section{SUBJECTIVE NORM QUESTIONAIRE}

Indicate your level of agreement with the following activities/behaviors in the context of the bolded statement by selecting from the following options:

1 - Strongly Disagree, 2 - Disagree, 3 - Neutral, 4 - Agree, 5 - Strongly Agree

\section{My parents think that...}

10. engaging in individual engagement activities (e.g., watching/reading the news, displaying buttons/signs in support of a candidate, contacting elected officials, attending rallies or protests, signing a petition) is important.

11. communicating with others about political elections (e.g., persuading others to vote, engaging in debates or watching debates, researching candidates) is important.

12. participating in political activities within school (e.g., giving a public speech on an important social issue, participating in student council, participating in a drive/campaign) is important.

13. participating in volunteer activities (e.g., donating food or clothes, participating in a fundraiser, participating in a community service project) is important.

\section{My closest friends think that...}

\begin{tabular}{|c|c|c|c|c|c|}
\hline $\begin{array}{l}\text { 14. engaging in individual engagement activities } \\
\text { (e.g., watching/reading the news, displaying } \\
\text { buttons/signs in support of a candidate, contacting } \\
\text { elected officials, attending rallies or protests, } \\
\text { signing a petition) is important. }\end{array}$ & 1 & 2 & 3 & 4 & 5 \\
\hline $\begin{array}{l}\text { 15. communicating with others about political } \\
\text { elections (e.g., persuading others to vote, } \\
\text { engaging in debates or watching debates, } \\
\text { researching candidates) is important. }\end{array}$ & 1 & 2 & 3 & 4 & 5 \\
\hline
\end{tabular}


16. participating in political activities within school (e.g., giving a public speech on an important social issue, participating in student council, participating in a drive/campaign) is important.

17. participating in volunteer activities (e.g., donating food or clothes, participating in a fundraiser, participating in a community service project) is important.

\section{People I admire think that...}

18. engaging in individual engagement activities (e.g., watching/reading the news, displaying buttons/signs in support of a candidate, contacting elected officials, attending rallies or protests, signing a petition) is important.

19. communicating with others about political elections (e.g., persuading others to vote, engaging in debates or watching debates, researching candidates) is important.

20. participating in political activities within school (e.g., giving a public speech on an important social issue, participating in student council, participating in a drive/campaign) is important.

21. participating in volunteer activities (e.g., donating food or clothes, participating in a fundraiser, participating in a community service project) is important.

\section{My teachers think that...}

22. engaging in individual engagement activities (e.g., watching/reading the news, displaying buttons/signs in support of a candidate, contacting elected officials, attending rallies or protests, signing a petition) is important.

$\begin{array}{lllll}1 & 2 & 3 & 4 & 5\end{array}$


23. communicating with others about political elections (e.g., persuading others to vote, engaging in debates or watching debates, researching candidates) is important.

24. participating in political activities within school (e.g., giving a public speech on an important social issue, participating in student council, participating in a drive/campaign) is important.

25. participating in volunteer activities (e.g., donating food or clothes, participating in a fundraiser, participating in a community service project) is important.

\section{SELF-EFFICACY QUESTIONAIRE}

Working with people, how hard or easy would it be for you to accomplish these goals?

1 - Extremely Not Effective, 2 - Not Effective, 3 - Neutral, 4 - Effective, 5 -

Extremely Effective

\begin{tabular}{|l|lllll|}
\hline 26. Getting potholes in your streets repaired & 1 & 2 & 3 & 4 & 5 \\
\hline 27. Solving problems on your campus & 1 & 2 & 3 & 4 & 5 \\
\hline $\begin{array}{l}\text { 28. Getting the town government to build an addition } \\
\text { to the local senior center }\end{array}$ & 1 & 2 & 3 & 4 & 5 \\
\hline 29. Organizing an event to benefit a charity & 1 & 2 & 3 & 4 & 5 \\
\hline $\begin{array}{l}\text { 30. Starting an after school program for children } \\
\text { whose parents work }\end{array}$ & 1 & 2 & 3 & 4 & 5 \\
\hline $\begin{array}{l}\text { 31. Changing academic offerings or requirements on } \\
\text { your campus }\end{array}$ & 1 & 2 & 3 & 4 & 5 \\
\hline 32. Influencing a state policy or budget decision & 1 & 2 & 3 & 4 & 5 \\
\hline $\begin{array}{l}\text { 33. Organizing an annual clean-up program for a city } \\
\text { park }\end{array}$ & 1 & 2 & 3 & 4 & 5 \\
\hline \begin{tabular}{l} 
34. Influencing the outcome of a local election \\
\hline $\begin{array}{l}\text { 35. Influencing decisions about who teaches on your } \\
\text { campus }\end{array}$
\end{tabular}$\quad 1 \quad 2$ & 3 & 4 & 5 \\
\hline
\end{tabular}




\section{ATTITUDES QUESTIONAIRE}

Indicate you level of agreement with the following statements by selecting from the following options:

1 - Strongly Disagree, 2 - Disagree, 3 - Neutral, 4 - Agree, 5 - Strongly Agree

\begin{tabular}{|c|c|c|c|c|c|}
\hline $\begin{array}{l}\text { 36. I become more effective in individual, political } \\
\text { engagement activities (e.g., watching/reading the } \\
\text { news, displaying buttons/signs in support of a } \\
\text { candidate, contacting elected officials, attending } \\
\text { rallies or protests, signing a petition), the more I } \\
\text { participate in them. }\end{array}$ & 1 & 2 & 3 & 4 & 5 \\
\hline $\begin{array}{l}\text { 37. It is good to be an effective participant in } \\
\text { political engagement activities. }\end{array}$ & 1 & 2 & 3 & 4 & 5 \\
\hline $\begin{array}{l}\text { 38. If I communicate with others about political } \\
\text { elections (e.g., persuading others to vote, } \\
\text { engaging in debates or watching debates, } \\
\text { researching candidates), I will be able to better } \\
\text { understand my own opinions. }\end{array}$ & 1 & 2 & 3 & 4 & 5 \\
\hline 39. It is good to understand my own opinions. & 1 & 2 & 3 & 4 & 5 \\
\hline $\begin{array}{l}\text { 40. If I participate in political activities within school } \\
\text { (e.g., giving a public speech on an important } \\
\text { social issue, participating in student council, } \\
\text { participate in a drive/campaign), I will strengthen } \\
\text { my understanding of politics. }\end{array}$ & 1 & 2 & 3 & 4 & 5 \\
\hline 41. It is good to understand politics. & 1 & 2 & 3 & 4 & 5 \\
\hline $\begin{array}{l}\text { 42. If I participate in volunteer activities (e.g., } \\
\text { donating food or clothes, participating in a } \\
\text { fundraiser, participating in a community service } \\
\text { project), I will be helping my community. }\end{array}$ & 1 & 2 & 3 & 4 & 5 \\
\hline 43. It is good to help the community. & 1 & 2 & 3 & 4 & 5 \\
\hline
\end{tabular}




\section{BEHAVIORAL INTENTION QUESTIONAIRE}

Indicate your likely participation in the following activities by indicating your future level of involvement or participation in the various activities after college.

1 - Never, 2 - Rarely, 3 - Occasionally, 4 - Often, 5 - Very Often

\begin{tabular}{|c|c|c|c|c|c|}
\hline 44. Volunteer for a community organization & 1 & 2 & 3 & 4 & 5 \\
\hline $\begin{array}{l}\text { 45. Watch/read the news on a daily basis (TV, } \\
\text { online, newspaper) }\end{array}$ & 1 & 2 & 3 & 4 & 5 \\
\hline 46. Boycott a specific service/good. & 1 & 2 & 3 & 4 & 5 \\
\hline $\begin{array}{l}\text { 47. Give a public speech about an important social } \\
\text { issue }\end{array}$ & 1 & 2 & 3 & 4 & 5 \\
\hline 48. Participate in student council/student government & 1 & 2 & 3 & 4 & 5 \\
\hline 49. Donate food, clothes, or money to a cause & 1 & 2 & 3 & 4 & 5 \\
\hline $\begin{array}{l}\text { 50. Attend a student council/student government } \\
\text { meeting }\end{array}$ & 1 & 2 & 3 & 4 & 5 \\
\hline 51. Contribute to a campaign & 1 & 2 & 3 & 4 & 5 \\
\hline 52. Participate in a fundraiser for an important cause & 1 & 2 & 3 & 4 & 5 \\
\hline 53. Persuade others to vote & 1 & 2 & 3 & 4 & 5 \\
\hline $\begin{array}{l}\text { 54. Display buttons or signs for candidates you } \\
\text { support }\end{array}$ & 1 & 2 & 3 & 4 & 5 \\
\hline 55. Vote in a state or national election & 1 & 2 & 3 & 4 & 5 \\
\hline 56. Watch or attend political debates & 1 & 2 & 3 & 4 & 5 \\
\hline $\begin{array}{l}\text { 57. Engage in a discussion/debate with family } \\
\text { members or friends about a political or social } \\
\text { issue }\end{array}$ & 1 & 2 & 3 & 4 & 5 \\
\hline 58. Participate in political campaign & 1 & 2 & 3 & 4 & 5 \\
\hline 59. Research political candidates running for office & 1 & 2 & 3 & 4 & 5 \\
\hline $\begin{array}{l}\text { 60. Contact elected officials (congress, president, } \\
\text { etc.) }\end{array}$ & 1 & 2 & 3 & 4 & 5 \\
\hline 61. Attend a rally or protest & 1 & 2 & 3 & 4 & 5 \\
\hline 62. Participate in a civic engagement project & 1 & 2 & 3 & 4 & 5 \\
\hline 63. Sign a petition & 1 & 2 & 3 & 4 & 5 \\
\hline
\end{tabular}




\begin{tabular}{|l|rrrrr|}
\hline 64. Contact media about a specific community issue & 1 & 2 & 3 & 4 & 5 \\
\hline 65. Attend a town hall meeting & 1 & 2 & 3 & 4 & 5 \\
\hline 66. Read or post on an online political blog & 1 & 2 & 3 & 4 & 5 \\
\hline $\begin{array}{l}\text { 67. Attend events sponsored by the American } \\
\text { Democracy Project or other organizations }\end{array}$ & 1 & 2 & 3 & 4 & 5 \\
\hline
\end{tabular}

\section{OPEN ENDED QUESTIONAIRE}

68. How have your past classroom experiences affected your views on volunteering, community issues, or politics?

69. How would you prefer topics regarding volunteering, community issues, or politics to be integrated into class assignments?

Open Ended Question

Open Ended Question 


\section{DEMOGRAPHICS}

\begin{tabular}{|c|c|}
\hline 70. What is your ethnic background/race? & $\begin{array}{l}\text { 1. White/Caucasian } \\
\text { 2. Hispanic/Latino } \\
\text { 3. Asian/Pacific Islander } \\
\text { 4. American Indian } \\
\text { 5. Black/African American } \\
\text { 6. Bi-racial or Mixed } \\
\text { 7. Other }\end{array}$ \\
\hline 71. What is your age? & years old \\
\hline 72. What is your sex? & $\begin{array}{ll}\text { 1. Female } \\
\text { 2. Male } \\
\text { 3. Transgendered } \\
\text { 4. Other }\end{array}$ \\
\hline 73. What is your year is school? & $\begin{array}{l}\text { 1. Freshman } \\
\text { 2. Sophomore } \\
\text { 3. Junior } \\
\text { 4. Senior } \\
\text { 5. Graduate Student }\end{array}$ \\
\hline $\begin{array}{l}\text { 74. What academic college can best categorize your } \\
\text { major? }\end{array}$ & $\begin{array}{l}\text { 1. College of Agriculture } \\
\text { 2. College of Applied Sciences } \\
\text { and Technology } \\
\text { 3. College of Arts and Sciences } \\
\text { 4. College of Architect and } \\
\text { Engineering } \\
\text { 5. College of Business } \\
\text { 6. College of Education } \\
\text { 7. College of Fine Arts } \\
\text { 8. College of Nursing }\end{array}$ \\
\hline $\begin{array}{l}\text { 75. How would you describe your political views? } \\
\text { Rate your political view from } 1 \text { (very } \\
\text { conservative) to } 10 \text { (very liberal). }\end{array}$ & Number Slider (1-10) \\
\hline
\end{tabular}


APPENDIX B

INFORMED CONSENT 


\section{CIVIC ENGAGEMENT ATTITUDES INFORMED CONSENT}

\section{Dear Student,}

I am a graduate student under the direction of Professor Baldwin in the School of Communication at Illinois State University. I am conducting a research study to understand the effect of learning about civic engagement in school. I am requesting your participation, which will involve 10 to 15 minutes of your time.

Your participation in this study is voluntary. If you choose not to participate or to withdraw for the study at any time, there will be no penalty, and it will not affect you in anyway. Your responses are anonymous (we will not track your IP address), and any information that might allow someone to identify you will not be disclosed. To participate, you must be at least 18 years of age.

There will be no risks involved with the participation in this research beyond those of everyday life. Although there may be no direct benefit to you, a possible benefit of you participation is furthering the development of pedagogical research with regards to civic engagement.

If you have any questions concerning the research study, please contact me at csjohn3@ilstu.edu.

If you have any questions about your rights as a subject/participant in this research, or if you feel you have been placed at risk, you can contact the Research Ethics \& Compliance Office at Illinois State University at (309) 438-2529.

Sincerely,

Chandler Johnson 
APPENDIX C

COPYRIGHT PERMISSION LETTER 
From: publications publications@carnegiefoundation.org

Subject: RE: Copyright for Thesis

Date: August 4, 2014 at 2:38 PM

To: Chandler Johnson csjohn3@ilstu.edu

You have our permission

Gay

Gay M. Clyburn

Associate Vice President, Public Affairs and Continuing Programs

Secretary to the Board of Trustees

Carnegie Foundation for the Advancement of Teaching

(office) 650 566-5162

(cell) 650 333-6974

www.carnegiefoundation.org

From: Chandler Johnson [mailto:csjohn3@ilstu.edu]

Sent: Sunday, August 03, 2014 10:27 AM

To: publications

Subject: Copyright for Thesis

Dear Carnegie Publication:

I am completing a thesis/dissertation at Illinois State University tentatively entitled "Advocating for Advocacy: How Academia Affects Sudents' Civic Engagement Outcome." I would like your permission to reprint in my dissertation excerpts from the following:

Colby, A., Beaumon, E., Ehrlich, T., \& Corngold, J. (2007). Educating for democracy: Preparing undergraduates for responsible political engagement. San Francisco, CA: Jossey-Bass

More specifically, I would like your permission to utilize and reproduce your Political Engagement Project (PEP) Survey in my research study.

I would like your permission to reproduce to use survey instrument in my research study. I would like to use and print your survey under the following conditions:

- I will use this survey only for my research study and will not sell or use it with any compensated or curriculum development activities.

- I will include the copyright statement on all copies of the instrument.

- I will send my research study and one copy of reports, articles, and the like that make use of these survey data promptly to your attention.

If these are acceptable terms and conditions, please indicate so by signing one copy of this letter and returning it to me via e-mail. Or, please contact me via e-mail or telephone (316-293-9311) if you would like to accept a different way.

Thank you very much.

Sincerely,

Chandler Johnson 
From: Ehrlich, Thomas tehrlich@stanford.edu

Subject: RE: Dissertation Permission Request

Date: July 27, 2014 at 1:00 PM

To: Chandler Johnson csjohn3@ilstu.edu

Cc: Colby, Anne acolby1@stanford.edu

\section{Dear Chandler Johnson:}

You have my permission on the conditions stated in your email. Good luck with your work. I am delighted that ours is helpful to you. Cheers. Tom Ehrlich

From: Chandler Johnson [mailto:csjohn3@ilstu.edu]

Sent: Sunday, July 27, 2014 9:34 AM

To: Ehrlich, Thomas

Subject: Dissertation Permission Request

Dear Dr. Ehrlich:

I am a graduate student in the School of Communication at Illinois State University writing my thesis on how the university classroom experience affects students' outcomes for civic engagement, as well as their likelihood to be civically engaged in the future. The is, tentatively titled, "Advocating for Advocacy: How Academia Affects Sudents' Civic Engagement Outcome," is under the direction of my dissertation committee chaired by Dr. John R. Baldwin.

I would like your permission to utilize and reproduce your Political Engagement Project (PEP) Survey in my research study. The graduate school at Illinois State University requires that permission is received from all copyright owners of scales prior to using them for research relating to a dissertation. Furthermore, I would like to use and print your survey under the following conditions:

I will use this survey only for my research study and will not sell or use it with any compensated or curriculum development activities.

I will include the copyright statement on all copies of the instrument.

I will send my research study and one copy of reports, articles, and the like that make use of these survey data promptly to your attention.

If these are acceptable terms and conditions, please indicate so by replying to this e-mail. If you have any questions, please do not hesitate to contact me either via email or phone (316-293-9311).

Thank you so much for taking the time to consider this request.

Sincerely,

Chandler Johnson 
From: Elizabeth Beaumont beaumont@umn.edu

Subject: Re: Dissertation Permission Requested

Date: July 27, 2014 at 7:53 PM

To: Chandler Johnson csjohn3@ilstu.edu, Colby, Anne acolby1@stanford.edu, Ehrlich, Thomas tehrlich@stanford.edu

Dear Chandler,

Thank you for your inquiry. I believe I can speak for my primary research partners on the PEP project, Anne Colby and Tom Ehrlich, in saying

that you are very welcome to use the PEP survey for your study. And we will all be very interested to learn of the results when you have the

dissertation completed!

Sincerely,

Liz Beaumont

Elizabeth Beaumont

Associate Professor of Political Science

University of Minnesota

267 - 19th Avenue South

1333 Social Sciences Building

Minneapolis, Minnesota 55455

beaumont@umn.edu

Author of The Civic Constitution: Civic Visions and Struggles in the Path toward Constitutional Democracy

On Sun, Jul 27, 2014 at 11:34 AM, Chandler Johnson <csjohn3@ilstu.edu> wrote:

Dear Dr. Beaumont:

I am a graduate student in the School of Communication at Illinois State University writing my thesis on how the university classroom experience affects students' outcomes for civic engagement, as well as their likelihood to be civically engaged in the future. The is, tentatively titled, "Advocating for Advocacy: How Academia Affects Sudents' Civic Engagement Outcome," is under the direction of my dissertation committee chaired by Dr. John R. Baldwin.

I would like your permission to utilize and reproduce your Political Engagement Project (PEP) Survey in my research study. The graduate school at Illinois State University requires that permission is received from all copyright owners of scales prior to using them for research relating to a dissertation. Furthermore, I would like to use and print your survey under the following conditions:

I will use this survey only for my research study and will not sell or use it with any compensated or curriculum development activities.

I will include the copyright statement on all copies of the instrument.

I will send my research study and one copy of reports, articles, and the like that make use of these survey data promptly to your attention.

If these are acceptable terms and conditions, please indicate so by replying to this e-mail. If you have any questions, please do not hesitate to contact me either via email or phone (316-293-9311).

Thank you so much for taking the time to consider this request.

Sincerely,

Chandler Johnson 
From: Colby, Anne acolby1@stanford.edu

Subject: RE: Dissertation Permission Requested

Date: July 27, 2014 at 10:57 PM

To: Chandler Johnson csjohn3@ilstu.edu

Sure Chandler. That would be fine.

Anne

From: Chandler Johnson [csjohn3@ilstu.edu]

Sent: Sunday, July 27, 2014 9:34 AM

To: Colby, Anne

Subject: Dissertation Permission Requested

Dear Dr. Colby:

I am a graduate student in the School of Communication at Illinois State University writing my thesis on how the university classroom experience affects students' outcomes for civic engagement, as well as their likelihood to be civically engaged in the future. The is, tentatively titled, "Advocating for Advocacy: How Academia Affects Sudents' Civic Engagement Outcome," is under the direction of my dissertation committee chaired by Dr. John R. Baldwin.

I would like your permission to utilize and reproduce your Political Engagement Project (PEP) Survey in my research study. The graduate school at Illinois State University requires that permission is received from all copyright owners of scales prior to using them for research school at Illinois State University requires that permission is received from all copyright owners of scales prior
relating to a dissertation. Furthermore, I would like to use and print your survey under the following conditions:

I will use this survey only for my research study and will not sell or use it with any compensated or curriculum development activities.

I will include the copyright statement on all copies of the instrument.

I will send my research study and one copy of reports, articles, and the like that make use of these survey data promptly to your attention.

If these are acceptable terms and conditions, please indicate so by replying to this e-mail. If you have any questions, please do not hesitate to contact me either via email or phone (316-293-9311).

Thank you so much for taking the time to consider this request.

Sincerely,

Chandler Johnson 
From: Christine Bruckner christinembruckner@gmail.com

Subject: Re: Dissertation Permission Requested

Date: July 28, 2014 at 12:36 PM

To: Chandler Johnson csjohn3@ilstu.edu

Chandler --

Please accept this email as an acceptance of your request to use and reproduce the aforementioned scales.

I wish you the best of luck on your thesis.

Thanks,

Christine Bruckner

On Sun, Jul 27, 2014 at 9:54 PM, Chandler Johnson <csjohn3@ilstu.edu> wrote:

Dear Mrs. Bruckner:

I am a graduate student in the School of Communication at Illinois State University writing my thesis on how the university classroom experience affects students' outcomes for civic engagement, as well as their likelihood to be civically engaged in the future. The is, tentatively titled, "Advocating for Advocacy: How Academia Affects Sudents' Civic Engagement Outcome," is under the direction of my dissertation committee chaired by Dr. John R. Baldwin.

I would like your permission to utilize and reproduce your thesis scales regarding behavior, attitude, norms, and intention for my research study. The graduate school at Illinois State University requires that permission is received from all copyright owners of scales prior to using them for research relating to a dissertation. Furthermore, I would like to use and print your survey under the following conditions:

I will use this survey only for my research study and will not sell or use it with any compensated or curriculum development activities.

I will include the copyright statement on all copies of the instrument.

I will send my research study and one copy of reports, articles, and the like that make use of these survey data promptly to your attention.

If these are acceptable terms and conditions, please indicate so by replying to this e-mail. If you have any questions, please do not hesitate to contact me either via email or phone (316-293-9311).

Thank you so much for taking the time to consider this request.

Sincerely,

Chandler Johnson 